\title{
Geographic distribution modeling and taxonomy of Stephadiscus lyratus (Cothouny in Gould, 1846) (Charopidae) reveal potential distributional areas of the species along the Patagonian Forests
}

\author{
Maria Gabriela Cuezzo ${ }^{\text {Corresp., } 1}$, Regina Gabriela Medina ${ }^{\text {Corresp., } 1}$, Carolina Nieto ${ }^{1}$ \\ 1 Instituto de Biodiversidad Neotropical, Consejo Nacional de Investigaciones Científicas y Técnicas (CONICET)-Universidad Nacional de Tucuman (UNT), \\ Yerba Buena, Horco Molle, Tucumán, Argentina \\ Corresponding Authors: Maria Gabriela Cuezzo, Regina Gabriela Medina \\ Email address: gcuezzo@webmail.unt.edu.ar, regina.g.medina@gmail.com
}

Background: Stephadiscus lyratus (Couthouy in Gould, 1846), an endemic Charopidae from southern South America, was described from few dry shells. The distribution of this species is known on scattering occurrences, mainly from material deposited in Museum collections. We provide here new information on anatomy, habitat, and microhabitat preferences and estimate the potential geographic distribution of the species to test if it is exclusively endemic to the Subpolar Magellanic Forest. Methods: Fieldwork was carried out in the National Parks of the Patagonian Forests. Snails were photographed, measured, and dissected for anatomical studies; shells were studied with scanning electron microscopy. Estimation of the species geographical distribution (EGD) was obtained through correlative ecological niche modeling (ENM). We designed a calibration area a priori with known species points of occurrence in the Magellanic Subpolar Forests and borders of the Patagonian steppe. Seven bioclimatic variables of the WorldClim database were used. The best ENMs were calibrated and selected using a maximum entropy method with Maxent v3.3.3K through the R package "kuenm". Candidate models were created by combining 4 values of regularization multiplier and all possible combinations of 3 feature classes. We evaluated candidate model performance based on significance (partial ROC), omission rates ( $E=5 \%$ ), and model complexity (AICC). From the best models obtained, a final model was transferred to a region "G" consisting of the calibration area plus the Valdivian Temperate Forests and whole Patagonian steppe, where we hypothesize that the species could be present. Finally, we obtained binary presence-absence maps. We quantified the proportion of the occurrence points and distribution range of $S$. lyratus in different land cover categories. To explore the degree of protection of $S$. lyratus'EGD, we quantified the proportion of its distributional range within protected areas. Results: A belobed kidney, a close secondary ureter, the terminal portion of the uterus forming a 
compact glandular mass, and the vas deferens with a dilatation are new anatomical information that distinguishes this species. Stephadiscus lyratus inhabit cold native forest areas, mainly living on or under humid logs in contact with the ground. The main constraining variables to explain S. lyratus distribution in the EGD were $\mathrm{BIO}, \mathrm{BIO12,} \mathrm{BIO6}$, and $\mathrm{BIO4}$. The potential area of distribution obtained almost duplicates their original range $\left(140,454 \mathrm{~km}^{2}\right)$ extending to the Valdivian Temperate forests mainly in Chile. Natural and semi-natural terrestrial vegetation was predominant in the potential area of distribution of S. lyratus. However, only $14.7 \%$ of this area occurs within current protected areas from Argentina and Chile. The ectothermic physiological traits of this species, low dispersal capacity, and its narrow habitat requirements turn S. lyratus into a potentially vulnerable species 
1 Geographic distribution modeling and taxonomy of Stephadiscus lyratus (Cothouny in

2 Gould, 1846) (Charopidae) reveal potential distributional areas of the species along the

3 Patagonian Forests

4

5 Maria Gabriela Cuezzo ${ }^{1}$, Regina Gabriela Medina ${ }^{1}$, Carolina Nieto ${ }^{1}$

6

$7 \quad{ }^{1}$ Instituto de Biodiversidad Neotropical, Consejo Nacional de Investigaciones Científicas y

8 Técnicas, Facultad de Ciencias Naturales, Universidad Nacional de Tucumán, Argentina

9

10

11 Corresponding authors:

12 MGC, Instituto de Biodiversidad Neotropical (IBN), Crisóstomo Álvarez 722, Tucumán, 13 Argentina. E-mail: gcuezzo@webmail.unt.edu.ar

14 RGM, Instituto de Biodiversidad Neotropical (IBN), Crisóstomo Álvarez 722, Tucumán, 15 Argentina. E-mail: regina.g.medina@gmail.com 
17 Abstract

18 Background: Stephadiscus lyratus (Couthouy in Gould, 1846), an endemic Charopidae from southern South America, was described from few dry shells. The distribution of this species is known on scattering occurrences, mainly from material deposited in Museum collections. We provide here new information on anatomy, habitat, and microhabitat preferences and estimate the potential geographic distribution of the species to test if it is exclusively endemic to the Subpolar Magellanic Forest. Methods: Fieldwork was carried out in the National Parks of the Patagonian Forests. Snails were photographed, measured, and dissected for anatomical studies; shells were studied with scanning electron microscopy. Estimation of the species geographical distribution (EGD) was obtained through correlative ecological niche modeling (ENM). We designed a calibration area a priori with known species points of occurrence in the Magellanic Subpolar Forests and borders of the Patagonian steppe. Seven bioclimatic variables of the WorldClim database were used. The best ENMs were calibrated and selected using a maximum entropy method with Maxent v3.3.3K through the R package "kuenm". Candidate models were created by combining 4 values of regularization multiplier and all possible combinations of 3 feature classes. We evaluated candidate model performance based on significance (partial ROC), omission rates $(\mathrm{E}=5 \%$ ), and model complexity (AICc). From the best models obtained, a final model was transferred to a region " $\mathrm{G}$ " consisting of the calibration area plus the Valdivian Temperate Forests and whole Patagonian steppe, where we hypothesize that the species could be present. Finally, we obtained binary presence-absence maps. We quantified the proportion of the occurrence points and distribution range of $S$. lyratus in different land cover categories. To explore the degree of protection of S. lyratus 'EGD, we quantified the proportion of its distributional range within protected areas. Results: A be-lobed kidney, a close secondary ureter, the terminal portion of the uterus forming a compact glandular mass, and the vas deferens with a dilatation are new anatomical information that distinguishes this species. Stephadiscus lyratus inhabit cold native forest areas, mainly living on or under humid logs in contact with the ground. The main constraining variables to explain S. lyratus distribution in the EGD were BIO3, BIO12, $\mathrm{BIO6}$, and BIO4. The potential area of distribution obtained almost duplicates their original range $\left(140,454 \mathrm{~km}^{2}\right)$ extending to the Valdivian Temperate forests mainly in Chile. Natural and semi-natural terrestrial vegetation was predominant in the potential area of distribution of $S$. lyratus. However, only $14.7 \%$ of this area occurs within current protected areas from Argentina 
and Chile. The ectothermic physiological traits of this species, low dispersal capacity, and its narrow habitat requirements turn $S$. lyratus into a potentially vulnerable species.

\section{Introduction}

Charopidae is a family of Punctoidea land gastropods with an extensive distribution that includes South America, South Africa, Australia, New Zealand, and Oceania (Salvador et al., 2020). Southern Argentina and Chile are particularly rich in endemic species of Charopidae (Miquel \& Cádiz Lorca, 2008). Hylton Scott $(1964,1968,1970,1973,1981)$ was the researcher that most studied and described Charopidae species in South America. Unfortunately, most of her descriptions were based on a single or few dry shells, which resulted in the absence of intraspecific shell variability studies. The lack of species anatomical data constitutes a barrier for intra family taxonomy. Also, adequate fieldwork to estimate the current distributional range of Charopidae genera and species in South America has not been done.

Stephadiscus Hylton Scott, 1981 originally included some species that are currently classified in Stephanoda Albers, 1860, and Stephacharopa Miquel \& Araya, 2013 (Miquel \& Barker, 2009; Miquel \& Araya, 2013). At present, the genus is formed by six species, Stephadiscus lyratus [designated as the genus type species], S. celinae (Hylton Scott, 1969), S. mirabilis (Hylton Scott, 1968), S. perversus (Hylton Scott, 1969), S. rumbolli (Hylton Scott, 1973), and S. stuardoi Miquel \& Barker, 2009. The taxonomic position of Stephadiscus striatus Hylton Scott, 1981 from northeastern Argentina and Venezuela, should have to be reconsidered, as it appears to belong to Punctidae (Miquel \& Barker, 2009). Known Stephadiscus distribution is restricted to Patagonia at both sides of the Andes from S $36^{\circ}$ towards the southernmost portion of the continent, including Malvinas islands (=Falklands) and southern archipelagos (Miquel \& Barker, 2009; Miquel \& Araya, 2013) and belong to the Andean region (Morrone, 2018). This biogeographic area has a closer relationship to the Austral region in the Austral kingdom (Morrone, 2015, 2018). The current distributional range of Stephadiscus lyratus (Couthouy in Gould, 1846) had been established on scattering points of occurrences taken from its original description, and subsequent species mentions (Gould, 1845-1848; Hylton Scott, 1972, 1981; Miquel \& Araya, 2013, see "Species remarks" section). Erroneous taxonomic identified material from Museum Collections suggested the presence of this species in the forests of northern Patagonia, even though Hylton Scott (1981) stated that S. lyratus could be a strictly Magellanic 
species. While Stephadiscus celinae, S. perversus, and S. mirabilis also occur in the Valdivian rainforest sub-ecoregion of northern Patagonia, S. rumbolli is exclusively from the southern subecoregions. For this reason, there are doubts as to whether the distribution of S. lyratus extends naturally to the Valdivian rainforest or is restricted to southern areas.

Modern methodologies to estimate a species distributional area involve the ecological niche models (ENMs) that relate the species distribution data (species occurrence at known locations) with information about the environment (abiotic factors) (Beltramino et al., 2015; Medina, Ponssa \& Aráoz, 2016). The environmental variables of the localities of occurrence are also informative about the species' potential distribution. Estimates of geographic range obtained by ENM techniques when data are scarce, or when species are rare, have proven to be more successful than those obtained by traditional methods (e.g., minimum convex polygon) (Marcer et al., 2013; Syfert et al., 2014; Pena et al., 2014). These also allow avoiding the potential subjective bias of experts (Fourcade et al., 2014). Furthermore, identifying the combination of environmental conditions in the relevant scenopoetic variables offers the opportunity to discover populations isolated (Wiens \& Graham, 2005). On the other hand, modeling species potential areas of distribution may also provide information on the geographic distribution of unknown sister species (Peterson et al., 2011).

Invertebrates are recognized as indicators of human disturbance, due to their low dispersal capacity and their dependence on microhabitats for survival and mating. Particularly, most snails that are not arboreal are dependent on litter from deciduous trees and have higher abundances in multispecies forests with strong broadleaf components (Addison \& Barber, 1997; Niemelä, 1997). Taking into account that many natural areas to date are severely fragmented or threatened by human activities, obtaining information on the ecological aspects of these species is very useful for future biological conservation work (Barahona-Segovia et al., 2019). Previous studies in Stephadiscus lyratus provided little data on habitat or microhabitat preferences and therefore future evaluation on its risk of extinction will need ecological information on this species. The objective of this research is to provide new information on the anatomy and ultrastructure of the Stephadiscus lyratus shell, using recently collected material, identifying and describing the microhabitat where it is found, and analyzing the environmental variables that are limiting its distribution with ENMs techniques. 
109 Finally, we estimate its potential geographic distribution to hypothesize if S. lyratus can also be

110 distributed in the Valdivian Temperate Forest or if this species is endemic exclusively to the

111 Magellanic Subpolar Forest.

112

113 Material and Methods

114 Study area (Fig. 1A, B)

115 Fieldwork was carried out in the Patagonian Forests, also known as the temperate forest of

116 southern South America that extends in a narrow strip of land over the Andes Mountain between

$11735^{\circ}$ and $55^{\circ}$ south latitude (Armesto et al., 2001). In Argentina, this region occupies the western

118 zone from the provinces of Neuquén to Tierra del Fuego and islands of the southern Atlantic.

119 The Patagonian Forests are divided into two different areas, the northern Valdivian Temperate

120 and the southern Magellanic Subpolar Forest ecoregions sensu Olson \& Dinnerstein (1998),

121 Olson et al. (2001) and Morello et al. (2012) or sub-ecoregions sensu Dos Santos et al. (2020).

122 We followed here this last-mentioned classification.

123 The Valdivian Temperate Forest (Fig. 1A) covers a narrow area running from $35^{\circ}$ to $48^{\circ}$ south

124 latitude between Chile and Argentina. Annual precipitation varies between 1,000 $\mathrm{mm}$ in the

125 north and more than 6,000 $\mathrm{mm}$ per year in the southern part of the sub-ecoregion. This seasonal

126 precipitation decreases significantly on the eastern slope of the Andes in Argentina, where

127 rainfall of less than $200 \mathrm{~mm}$ is recorded only $100 \mathrm{~km}$ east of the Andean peaks. Maximum

128 annual average temperatures vary between $21{ }^{\circ} \mathrm{C}$ and $13{ }^{\circ} \mathrm{C}$ in the northern and southern ends of

129 the sub-ecoregion. Minimum annual average temperatures range from $7{ }^{\circ} \mathrm{C}$ to $4{ }^{\circ} \mathrm{C}$

130 (https://www.worldwildlife.org/ecoregions/nt0404). Biogeographically, these forests share

131 floristic similarities with other temperate forests in the southern hemisphere located in Australia

132 and New Zealand (McGlone et al., 2016). However, there is a high degree of endemism not only

133 in the flora but also in the fauna at the species level.

134 The southern areas of the Magellanic Subpolar Forests are well represented in Tierra del Fuego,

135 where they occupy the entire south of the province (Fig. 1A, B). However, the dominant

136 vegetation is a forest of less species diversity in comparison to the Valdivian rainforest due to the

137 low temperatures and rainfall.

138 Tierra del Fuego or Fueguia is the archipelago located south of the Strait of Magallanes between

$13952^{\circ} 28^{\prime} \mathrm{S}$ and $55^{\circ} 03^{\prime} \mathrm{S}$; it occupies about $66,000 \mathrm{~km}^{2}$ (Fig. 1A). The main island is Isla Grande, 
with $48,000 \mathrm{~km}^{2}$ representing $70 \%$ of the surface of the archipelago, from which $21,263 \mathrm{~km}^{2}$ belongs to Argentina (Frangi et al., 2004). The vegetation of the island is mainly formed by a Patagonian steppe of grasslands and shrubs located at the northern part, and humid deciduous and evergreen forests plus peat bogs located in the center and southern portion. The trees of the genus Nothofagus dominate the forest composition in Tierra del Fuego and constitute the most austral forest in the world as part of the Magellanic Subpolar forest sub-ecoregion. The highest rainfall is recorded in the south of the island, decreasing to the east and center of it. In the south and west of the island, it is very windy, foggy, and humid most of the year with few days without rain, sleet, hail, or snow. The average annual temperature on the island is $5.5^{\circ} \mathrm{C}$ to the north and $5.9^{\circ} \mathrm{C}$ to the south. Above the mountains, the temperature decreases with elevation, these gradients determine temperatures below zero in the winter months (Frangi et al., 2004). The Big Island of Tierra del Fuego and the Islas de Los Estados were modeled by the erosive action of glaciers that covered large portions of land on several occasions. The glacial topography and the temperate-cold and humid climate that prevail throughout the year favored the formation of the peat bogs that are now part of the Fuegian landscape.

\section{Fieldwork and specimen collections}

Fieldwork was carried out in the Magellanic Subpolar Forests of Tierra del Fuego National Park (DRPA 146/2019) and other non-preserved areas in Isla Grande of Tierra del Fuego, Argentina, during December 2018 - January 2019 (Figs. 1C, D). In the Valdivian Temperate Forests, fieldwork was done within Los Alerces National Park and Puerto Blest in Nahuel Huapi National Park (DRPA 1674, DFyFS1/19) during January 2020. We qualitatively searched for land snails along transects for half an hour in each collecting site. Searching was mainly focused on microhabitats that seem to be most favorable for snails, such as between exposed roots of trees, under the bark of trees, under rocks, or under tree trunks lying on the forest floor in contact with soil. In each collecting site, we recorded altitude and geographic coordinates. We also took samples of $50 \times 50 \mathrm{~cm}$ quadrats of leaf litter $+2 \mathrm{~cm}$ of topsoil from moist microhabitats. Samples were placed in plastic bags and posteriorly sieved through three decreasing mesh widths $(3,1.5$, and $0.5 \mathrm{~mm}$ ) in the laboratory of the Centro Austral de Investigaciones Cientificas (CADICCONICET, Tierra del Fuego) under a stereoscopic microscope. All snails collected were photographed alive before relaxing them in water for 24 hours, posteriorly fixed in ethanol $96 \%$, 
171 and preserved in ethanol 70\% for anatomical studies. Several specimens were also fixed directly

172 in ethanol 96\%, without relaxation in water, for future molecular studies. All the material

173 collected was deposited in the Malacological Collection of the Instituto de Biodiversidad

174 Neotropical (IBN, CONICET-UNT, Tucumán, Argentina).

175 Morphology

176 Ten adult shells were photographed using a Zeiss Stemi 508 with ActionCam and measured

177 using the software Image 1.49 (Schneider, Rasband \& Eliceiri, 2012). Shell measurements

178 selected, on dorsal and lateral views, are major shell diameter (DM), shell minor diameter (Dm),

179 shell height (H), apertural height (Hap), and apertural diameter (Dap). The number of shell

180 whorls was calculated following the Kerney \& Cameron (1979) methodology. Photographs and

181 shell measurements were carried out at the CADIC in Tierra del Fuego. For anatomical

182 information, dissections of 7 adult specimens were studied under a Leica MZ6 stereoscope.

183 Illustrations of the dissected organs/systems were carried out with the aid of a camera lucida. The

184 terms proximal and distal refer to the position of an organ or part of an organ in relation to the

185 gamete flow from ovotestis (proximal) to genital pore (distal) as in previous works (Cuezzo,

186 2006; Cuezzo et al., 2018). The distinction of the limits between the epiphallus and penis is

187 based on the internal sculpture of their inner wall. Shell ultrastructure was studied and described

188 using a SEM Zeiss Supra 55VP at the Integral Center of Electron Microscopy (CIME) of the

189 National University of Tucumán, Argentina (UNT).

190

\section{Occurrence records}

192 We compiled a total of 60 geographic records of Stephadiscus lyratus from field surveys, 193 museum collections, and scientific articles (Fig. 1, Table S1). Twenty new reliable records were 194 obtained through fieldwork in Tierra del Fuego. To avoid primary taxonomic sources of error 195 from specimens deposited at different Museums, we corroborated the taxonomic identification of 196 specimens according to their shell morphology. The malacological collections of IBN (Instituto 197 de Biodiversidad Neotropical, Tucumán, Argentina), MACN-In (Museo Argentino de Ciencias 198 Naturales Bernardino Rivadavia, Buenos Aires, Argentina), and MLP (Museo de La Plata, 199 Buenos Aires, Argentina) were revised accordingly. Other sources of information were 200 electronic databases from the Smithsonian National Museum of Natural History (NMNH), 201 Museum of Comparative Zoology (MCZ), and Academy of Natural Sciences in Philadelphia 
202 (ANSP). We used Google Earth to georeferenced localities of occurrences that lacked

203 geographic coordinates. From the total number of records, we removed duplicate records, which

204 left 37 unique sites with trustable geographic information. To avoid over-representation of

205 certain environmental combinations, we spatially filtered records based on a $5 \mathrm{~km}$ radius, which

206 left 24 localities, then we split them in 30\% for test and 70\% for train the ecological niche model,

207 both functions implemented in R-package “ellipsenm” (Cobos et al., 2020).

208

209 Estimations of potential geographic distributions (EGDs)

210 Estimates of the geographical distribution (EGD) of S. lyratus were obtained through correlative

211 ecological niche modeling (ENM). To adequately model the species niche, we used the

212 theoretical Biotic-Abiotic-Mobility framework (Soberón \& Peterson, 2005). Only abiotic and

213 mobility factors were taken into account because the biotic components (i.e., biotic interactions)

214 are virtually impossible to spatially quantify thoroughly at regional scales (Peterson et al., 2011).

215 As for the mobility component, we designed a calibration area a priori "M" (Barve et al., 2011)

216 considering sub-ecoregions with known species points of occurrence, i.e., in the Magellanic

217 Subpolar Forest and the southern portion of the Patagonian steppe. To delineate abiotic

218 components, we used 15 bioclimatic variables of the WorldClim database (Hijmans et al., 2005)

219 at a spatial resolution of 30 arc seconds $\left(\sim 1 \mathrm{~km}^{2}\right)$, excluding the four variables that combine

220 temperature and precipitation owing to be known artifacts (Escobar et al., 2014). We clipped the

221 environmental data layers to the calibration area defined. To eliminate one variable per pair of

222 highly correlated variables $(r \geq 0.85)$, we performed a correlation analysis through the "ntbox"

223 package (Osorio-Olvera et al., 2020). Thus, seven bioclimatic variables were selected for the

224 analyses: $\mathrm{BIO} 1=$ Annual mean temperature, $\mathrm{BIO} 2=$ Mean diurnal range (Mean of monthly

225 (max temp - min temp)), BIO3 = Isothermality $(\mathrm{BIO} 2 / \mathrm{BIO} 7)(* 100), \mathrm{BIO} 4=$ Temperature

226 seasonality ( standard deviation *100), BIO6 = Min temperature of coldest month, BIO12=

227 Annual precipitation, and BIO15 = Precipitation seasonality (Coefficient of variation).

228 The best ENMs were calibrated and selected using a maximum entropy method with Maxent

229 v3.3.3K (Phillips, Anderson \& Schapire, 2006) through the R package "kuenm" (Cobos et al.,

230 2019). Then, candidate models were created by combining four values of regularization

231 multiplier $(0.1,0.5,1,2)$, and all possible combinations of three feature classes (linear $=1$,

232 quadratic $=q$, product $=\mathrm{p}$ ). We evaluated candidate model performance based on significance 
233 (partial ROC, with 100 iterations and 50 percent of data for bootstrapping), omission rates $(\mathrm{E}=$

$2345 \%$ ), and model complexity (AICc). Best models were selected according to the following

235 criteria: (1) significant models with (2) omission rates $\leq 5 \%$. From among this set, models with

236 delta AICc values of $\leq 2$ were chosen as final models. The final model was created using the

237 spatially filtered records (24 occurrences) and the selected parameterizations. We produced 100

238 iterations with five replicates by bootstrap, with logistic outputs. We ran the models with no

239 extrapolation or clamping to avoid artificial projections based on extreme values of the

240 bioclimatic variables (Elith et al., 2011; Owens et al., 2013; Merow et al., 2014; Guevara et al.,

241 2018). Then, the final model was transferred to a region " $G$ " consisting of the calibration area

242 plus the Valdivian Temperate Forest and Patagonian steppe regions, where the species could be

243 also present as its congeners. To identify extrapolation risk areas in model transfers, we

244 performed MOP analyses (Owens et al., 2013). This function calculates multivariate

245 environmental distances between sites across the transfer region $(\mathrm{G})$ and the nearest portion of

246 the calibration region to identify areas that have a condition of strict or combinational

247 extrapolation.

248 Finally, to obtain binary presence-absence maps, we used a minimum presence threshold,

249 modified to consider presence data errors (Peterson, Papeş \& Eaton, 2007) implemented in R-

250 package "ENMGadgets" (Barve \& Barve, 2019). This modified threshold included 100\% of the

251 presence points minus the dataset error (E) (Phillips \& Dudík, 2008); we assumed E = 5\% based

252 on our experience of obtaining the presence data. This conservative method minimizes the

253 commission error rate.

254

255 Spatial analysis

256 To spatially characterize the distribution of Stephadiscus lyratus we quantified the proportion of

257 occurrences points and their potential distribution in different categories of the land cover of the

258 Globcover 2009 dataset (Arino et al., 2012). The 22 land cover categories (e.g., Closed to open

$259(>15 \%)$ broadleaved evergreen or semi-deciduous forest $(>5 \mathrm{~m})$, Mosaic forest or shrubland (50-

$26070 \%$ ) / grassland (20-50\%)) are according to the UN Land Cover Classification System (LCCS)

261 (Di Gregorio, 2005).

262 To explore the degree of protection of S. lyratus' EGD, we quantified the proportion of its range

263 within protected areas. We take into account the protected areas categories I to VI assigned by

Peer] reviewing PDF | (2020:12:56538:2:0:NEW 13 May 2021) 
264 the International Union for Conservation of Nature (IUCN) (Dudley, 2008) and the National

265 Parks, even though these are not included in any IUCN category. Shapefiles of the protected

266 areas were obtained from the World Database of Protected Areas (IUCN \& UNEP-WCMC,

267 2020) and http://mapas.parquesnacionales.gob.ar/.

268

269 Results

\section{Systematic account}

271 Superfamily Punctoidea Morse, 1864

272 Family Charopidae Hutton, 1884

273 Subfamily Charopinae Hutton, 1884

274

275 Stephadiscus Hylton Scott, 1981

276 Type species: Helix lyratus Couthouy in Gould, 1846, by original designation.

277

278 Species description (Figs 2, 3, 4)

279 Stephadiscus lyratus (Couthouy in Gould, 1846)

$280 \quad$ Helix lyrata Couthouy in Gould, 1846: 167; 1852: 39.

281 Patula rigophila Mabille, 1886: 123.

282 Amphidoxa lirata Pilsbry, 1894: 41.

283 Amphidoxa (Stephanoda) lyrata Smith, 1905: 339

284

285

Stephanoda lyrata Pilsbry, 1911, 518; Hylton Scott, 1972: 67.

286

287 Syntype: MCZ 88297 MCZ: Museum of Comparative Zoology, Harvard University

288 Type locality: Orange Harbor, Tierra del Fuego [according to Johnson (1964): located at the west 289 side of Nassau Bay].

Morphology (Figs 2-4)

292 External body morphology (Fig. 2A-B)

293 Animal black with lighter foot and mantle collar around shell aperture. A deep longitudinal

294 furrow, the pedal groove, runs parallel to the foot edge on each side and above it. Dark irregular 
295 spots are seen for transparency through the shell, although some specimens are lighter. Foot 296 short, triangular pointed, not to slightly surpassing the shell diameter.

297 Shell (Figs. 2 C-E; 3A-E): Discoidal, $3 \frac{1}{2} 2$ to 4 convex regularly expanded whorls, low spire

298 depressed, not planispiral as apex elevated, fragile (DM=4,247-5,041mm; Dm=3,444 -

$2994,487 \mathrm{~mm} ; \mathrm{H}=2,283-2,432 \mathrm{~mm}$ ) with brown caramel to light whitish color (Figs. 2 A-E).

300 Protoconch with 35 - 40 axial delicate, smooth, elevated ribs separated at regular intervals (Fig.

301 3A). Spaces between protoconch ribs with thinner axial costulae. Protoconch not clearly

302 delimited from the teleoconch, and similarly sculptured. Teleoconch surface with major axial 303 ribs (Figs. 3B-D), interspace between them of 4-7 $\mu \mathrm{m}$ filled with 5 to 7 micro radial costulas in

304 between major ribs, nodules at regular intervals supporting ribs, giving the appearance of radial 305 cords (Figs. 3B-C). Deep irregular suture (Fig. 3D). Circular aperture, not descendent, with sharp 306 peristome (Hap=1,861-2,110; Dap=1,809-1,998). Umbilicus 1/3 or slightly less of body whorl 307 major diameter, with same sculpture as nepionic portion of the shell (Fig. 3E).

308 Pallial system (Fig. 4A): Pulmonary roof dark with black spots and whitish small granules over 309 the surface. Spots and granules visible through shell. Pulmonary sac short occupying 1/4 of body whorl. Kidney triangular, bilobated, with pericardial side lobe overlapping pericardium. Rectal side kidney lobe bigger than pericardial arm. Principal pulmonary vein short, slender, not branched, smoothly marked. Remaining pulmonary roof smooth with no other veins. Secondary ureter present, close along its length, parallel to rectum. Pallial gland absent. Jaw and radula: Jaw consists of narrow vertical plates, slightly arched, cream-colored. Radula as described by Hylton Scott (1970).

Reproductive system (Figs. 4B-E): Albumen gland shapeless, roughly globular, rounded margins.

317 Spermoviduct formed by prostate and uterus fused. Uterus divided into two portions, proximal

318 short, cylindrical, continuous to albumen gland, distally expanded in a rounded glandular 319 chamber (Figs. 4B, C). Free oviduct cylindrical, short. Bursa copulatrix sac round, resting over uterus distal portion. Duct of bursa copulatrix basally thickened, progressively decreasing in diameter towards the sac (Fig. 4D). Vagina as long as bursa copulatrix duct, distally widened, featuring three thick, longitudinal pilasters on the interior wall. Vas deferens cylindrical, narrow in diameter, short, running from basal prostate towards peni-oviducal angle, inserting into epiphallus. Penial retractor thin, inserted in penis. Penis cylindrical, thicker than epiphallus, with a sac-like appendix in upper portion (Fig. 4C-E). Short verge in upper penial chamber, inner 
326 penial wall with short pilaster noticeable towards middle penis length. Epiphallus reflected over

327 penis, shorter, thinner ending in a short finger-like flagellum (Fig. 4E). Vas deference delated

328 before inserting into epiphallus anteriorly of penial retractor insertion, dilatation as long as

329 flagellum, giving the appearance of fork ending epiphallus.

330

331

Microhabitat characterization

332

333

334

335

336

337

338

339

340

341

342

343

344

345

346

347

348

349

350

351

352

353

354

355

356

Rainforests, including temperate forests, provide a variety of living spaces where snails can feed, crawl, and live. Although micro snails are usually associated with leaf litter, Stephadiscus lyratus was mainly found living on or under the bark of fallen trees or under humid logs in contact with the ground (Figs. 1C, D). We found actively crawling snails only on tree barks or on moss logs. This species is not considered to be arboreal or semi-arboreal. No specimens were found in living trees, nor in their leaves or shrubs, the majority of alive snails were found under fallen decaying logs in contact with the ground. During the hibernation period in wintertime, these microhabitats in contact with soil can act as a buffer and help the species to survive during extreme freezing conditions. Dry shells were recovered from soil samples, but in general, they were worn out. Feeding habits in this species are not known. However, the diversity of fungi from the decaying wood is an important food resource for snails (Solem, 1982; Barker, 2001). Species of the genus Radiodiscus occur in sympatry with S. lyratus. In places outside protected areas where the forest shows some degree of alteration, living snails were scarce or difficult to find.

\section{Species Remarks}

The history of the species discovery as well as the problem of the species authorship is explained in Supplementary Material (See Appendix).

Comparison with species of the same genus: S. lyratus has the largest shell diameter (DM= 5.5 $\mathrm{mm}$ ) among all species classified in Stephadiscus. It is a very conspicuous species regarding its shell coloration and sculpture. Although $S$. perversus is similar in shell coloration, it cannot be confused with $S$. lyratus because it is sinistrorse and has a smaller shell (DM=2, 8; $\mathrm{H}=1.5 \mathrm{~mm})$. Stephadiscus lyratus is also similar in shell sculpture and general shape to $S$. stuardoi (DM=2.0$2.02, \mathrm{H}=0.85$ ), but differs from this species in its larger shell diameter and the absence of weak 
357 spiral threads in the teleoconch. In the original description, Couthouy in Gould mentioned that $S$.

358 lyratus could be a synonym of Helix costellata d'Orbigny, 1835 (now Zilchogyra costellata

359 (d'Orbigny, 1835)). However, H. costellata is distributed in the Humid Pampa ecoregion in

360 Buenos Aires, Argentina, an extra Patagonian area with completely different ecological

361 requirements. $H$. costellata $(\mathrm{DM}=4 \mathrm{~mm}, \mathrm{H}=2 \mathrm{~mm})$ is smaller in shell diameter and height than

362 S. lyratus and its protoconch is a smooth surface.

363 Stephadiscus lyrata and S. mirabilis are the only species of the genus with known anatomies.

364 Both show a rounded glandular mass, identified as a "dilated sac" by Hylton Scott (1970) at the

365 base of the spermiduct, in the distal genitalia. A similar structure is also present in

366 Stephacharopa testalba (Hylton Scott, 1970). Most of the described species of the genus have

367 been originally established only on single or two dry shells (Table S2), and after their discovery,

368 rarely fresh specimens have been collected in their area of distribution.

369

370

Comparison with related genera: Stephadiscus is defined by having plane-convex whorls,

presence of a protoconch, and teleoconch with similar ornamentation consisting of thin, nodulose ribs, without a marked limit between the protoconch and the teleoconch (Hylton Scott, 1981; Miquel \& Araya, 2013). Therefore, the transition of protoconch towards teleoconch is barely distinguished. These ribs increase in height towards the body whorl, with thinner costula in the interspaces. Stephadiscus is different from Stephacharopa Miquel \& Araya, 2013 because in the latter genus, the sculptured protoconch is dissimilar to the teleoconch ornamentation while in the former, the sculptured protoconch is similar to the one present in the teleoconch. Stephadiscus differs from Stephanoda mainly in the sculpture of the protoconch, since the latter possesses a reticulated pattern. Differences in anatomy are not possible to be established for the lack of studies on these genera. Other South American charopid genera, such as Lilloiconcha Weyrauch, 1965 and Zylchogyra Weyrauch, 1965 can reach similar shell sizes but differ from Stephadiscus in general shell shape and in that their protoconch is smooth (Miquel \& Araya, 2013). S. lyratus shows a specialized vas deferens-epiphallus junction as other subfamilies Semperdoninae, Trukcharopinae, and Rotadiscinae. 
388 We obtained 24 candidate models statistically significantly better than null expectations (i.e.,

389 predictions from the models coincided with testing occurrence data more frequently than would

390 be expected by random association of points and a prediction of that areal extent) (Table S3).

391 From these, only one final model was selected that was statistically significant and met the AICc

392 criteria (two of three selection criteria) (Table S4). The chosen settings were linear, quadratic,

393 and product features and 0.1 of regularization multiplier. The bioclimatic variables that most

394 contribute to the model were BIO3 = Isothermality $(\mathrm{BIO} 2 / \mathrm{BIO} 7)(\times 100), \mathrm{BIO} 12=$ Annual

395 precipitation, $\mathrm{BIO} 6=$ Minimum temperature of the coldest month, and $\mathrm{BIO} 4=$ Temperature

396 seasonality (standard deviation of mean month temperature * 100) (47\%, 17\%, 12\% and $11.5 \%$

397 percent of contribution, respectively). Response curves also gave an indication of the range

398 under which the variable reaches its optimum suitability. The optimum suitability for

399 isothermality is around $43 \%$ to $55 \%$, from here decreased abruptly to cero, which indicates that

400 day to night temperature oscillations are smaller than annual temperature fluctuations (Fig. 5A).

401 BIO4, BIO6, and BIO12 displayed a bell-shaped response of increased suitability as the variable

402 increases above a certain value (Fig. 5B-D). The optimum suitability of BIO4 is around 2750,

403 this is a measure of temperature change over the year, the larger the value (standard deviation of

404 mean monthly temperature x 100), the greater the variability of temperature (O'Donnell \&

405 Ignizio, 2012). The optimum suitability of BIO6 is between -2 and $0{ }^{\circ} \mathrm{C}$ (around $-1{ }^{\circ} \mathrm{C}$, Fig. $5 \mathrm{C}$ ),

406 this is a measure of minimum cold temperatures throughout the year. In the case of BIO12, the

407 species had its maximum suitability in the 500-600 mm within a narrow range that abruptly

408 decreased when the precipitation increased above this threshold (Fig. 5D).

409

\section{Spatial analysis}

411 The known area of distribution of $S$. lyratus was approximately $72,672 \mathrm{~km}^{2}$, mainly coincident in

412 the southern portion of the Magellanic Subpolar Forest (below $-51^{\circ}$ of latitude), at both sides of

413 the Andes and marginally in the southern part of Patagonian steppe in Tierra del Fuego (Fig.

414 6A). The MOP analysis (Fig. S1) indicated that areas with the most dissimilar variables

415 conditions (i.e., where one or more environmental variables are outside the range present in the

416 training data) were found beyond the potential distributional areas predicted by the model in the

417 “G” area. 
418 When the final model is transferred to region " $\mathrm{G}$ ", we found that the potential area of distribution

419 almost duplicates their original range $\left(140,454 \mathrm{Km}^{2}\right)$. This new region extends mainly to the

420 Valdivian Temperate Forest between -40 and -46 latitude, mostly in Chile and a small portion of

421 Argentina, while towards the Patagonian steppe increase marginally (Fig.6B).

422 Natural and semi-natural terrestrial vegetation was predominant in the occurrence points and the 423 potential area of distribution of S. lyratus. The occurrences points overlap a 33\% and the EGD a $42448 \%$ with woody trees (closed to open $(>15 \%)$ broadleaved evergreen or semi-deciduous forest $425(>5 \mathrm{~m})$ ), while the overlap with shrub (closed to open $(>15 \%)$ (broadleaved or needle-leaved, 426 evergreen or deciduous shrubland) was a $31 \%$ and $21 \%$, respectively (Table 1).

427 The proportion of the potential distribution area in protected areas was $14.7 \%$, occurring in 16 428 protected areas, from which six of them are located in Argentina while the remaining are from 429 Chile. The higher proportional area protected is due to National Parks "Alberto D'Agostini” and 430 "Yendegaia" (Chile), and Multiple Use Provincial Reserve "Corazon de la Isla Tierra del Fuego 431 (Argentina). Taking into account the category of management of IUCN, nine are category II 432 National Parks and Ib Wilderness Nature Reserve; the six remaining are category IV Forest 433 Reserve and VI Multiple Use Provincial Reserve (Table 2).

435 Discussion

436 Taxonomy and Species Morphology

437 Features of the gastropod shell have always been an essential and convenient source of 438 taxonomic information. However, it is well recognized that shell characters such as shape, 439 coiling patterns, and ribbing can be convergent and often mask crucial differences in anatomy 440 (Stanisic, 1990; Barker, 2001). Hylton Scott, understanding the value of anatomical information, 441 was the only researcher to provide anatomical descriptions of some South American charopids 442 such as Stephacharopa testalba, Stephadiscus lyratus, S. mirabilis, Zilchogyra leptotera 443 (Mabille, 1886). Recently, a study on Punctoidea phylogeny provided molecular information on 444 some charopid species (Salvador et al., 2020). Stephadiscus lyratus, as all the species of the 445 genus, has similar ornamentation in the shell protoconch and the teleoconch, without a marked 446 limit between them. The type of ornamentation and similitude between protoconch and 447 teleoconch differences Stephadiscus from all other South American charopid genera (Miquel \& 448 Cádiz Lorca, 2008; Miquel \& Barker, 2009; Miquel \& Araya, 2013). Inner anatomy information 
449 proves to be an essential source of characters relevant for future taxonomic and phylogenetic 450 studies. The presence of a be-lobed kidney with the rectal side lobe bigger than the pericardial 451 portion, plus the presence of a close secondary ureter, clearly indicates that $S$. lyratus belongs to 452 Charopidae, differencing it from the Endodontidae. Solem (1982) raised these characters as the 453 main differences between both families. The terminal portion of the uterus (spermoviduct), 454 forming a compact glandular mass, is also a striking character that has only been mentioned 455 before for Stephacharopa testalba. Along with this, the insertion of the vas deferens into the 456 epiphallus through a dilatation constitutes unique structures of S. lyratus.

457

Estimation of the potential geographical distribution (EGD) and spatial analysis.

459 The new records obtained were associated with native areas of the Magellanic Subpolar Forest 460 sub-ecoregion in Argentina. The transferred model shows a potential distribution of S. lyratus to 461 the Valdivian Temperate Forest, spreading the known area to a new sub-ecoregion, 462 corresponding mainly to the area of this mentioned zone in Chile. Although no specimens of $S$. 463 lyratus have been found in the Valdivian forest areas in Argentina (Nahuel Huapi and Los 464 Alerces National Parks), these surveyed areas are outside to the east of the potential area 465 predicted by the model. Thus, the potential area of distribution of S. lyratus is coincident with the 466 Magellanic Subpolar Forest and the Valdivian Temperate Forest (more towards Chile) together 467 with its boundaries with the Patagonian Steppe ecoregion. The obtained hypothesis of the 468 potential distribution of $S$. lyratus will direct the next exploratory surveys with the expectation to 469 find new populations in the future.

470 The biogeographic Valdivian Forest province according to Kuschel (1960) and Morrone (2018)

471 has faunistic relationships with Magellanic Forests, probably because both regions have been

472 isolated from other South American forests since the Neogene (Axelrod, Kalin Arroyo \& Raven, 473 1991). In addition, the cooling cycles followed by warmer periods in the Quaternary caused the 474 contractions and expansions of the temperate forests (Villagrán \& Hinojosa, 1997), and some 475 areas in the coastal range remained free of ices and may have been the source for the recovery of 476 the forest biota (Smith, 2017). From the seven environmental variables used in the EGD analysis 477 of $S$. lyratus, the main constraining variables are the temperature $(\mathrm{BIO} 3=$ Isothermality, $\mathrm{BIO} 6=$ 478 Minimum temperature of coldest month, and BIO4 = Temperature seasonality) and Annual 479 precipitation $(\mathrm{BIO} 12)$. 
480 Other studies using native snails in South America that analyzed the role of abiotic factors 481 concerning their distribution are scarce e.g., the case of Megalobulimus sanctipauli (Ihering \& 482 Pilsbry, 1900). This kind of study for native micro snails is virtually nonexistent. Megalobulimus 483 sanctipauli, known to inhabit the Atlantic Forest, showed temperature and rainfall as the 484 determinant factors of their geographic distribution (Beltramino et al., 2015). In the case of

485

486

487

488

489

490

491

492

493

494

495

496

497

498

499

500

501

502

503

504

505

506

507

508

509

510
Achatina fulica Bowdich, 1822, an exotic land gastropod in South America, Temperature seasonality, and Mean temperature of the coldest quarter were the variables that contribute the most to the model when they were used alone (Vogler et al., 2013). In the case of S. lyratus, the bell-shape response of environmental suitability for the $\mathrm{BIO} 4, \mathrm{BIO} 6$, and $\mathrm{BIO} 12$ show that the studied species try to avoid extreme temperature and precipitation oscillations. The BIO6 variable shows predicted suitable conditions at sub-zero temperatures. It suggests that this climatic variable is relevant for its optimal growing conditions and in particular with the species' winter survival. Indeed, S. lyratus is found in the Magellanic Subpolar Forest where winter temperatures can drop below $0^{\circ} \mathrm{C}$. Empirical data on the life history of small land snail species in their natural habitat are hardly available worldwide. There is also very little data on gastropod cold hardiness, especially on land snail species of small sizes. Ansart \& Vernon (2003) sustained that two alternatives exist for organisms living in areas that freeze in winter, such as the southern forest in Patagonia: move to an unfrozen habitat or face freezing conditions. For this last category, avoid freezing by extensive supercooling (freezing avoidance) or survive freezing of the body fluids (freezing tolerance) are the only possibilities. Freezing avoidance involves the choice of a hibernation site, which buffers the temperature differences, and which permits avoidance of inoculative freezing (e.g., by contact with ice). During hibernation, the snails rapidly suppress their metabolism and minimize water loss using a discontinuous gas exchange pattern (Koštál et al., 2013). We sustain that S. lyratus find favorable overwintering microhabitat in soil, under tree bark, or under fallen tree trunks in contact with soil, which is well buffered from temperature and moisture fluctuations allowing the species to survive during winter freezing.

Decaying wood can absorb and retain water for several weeks during periods of low precipitation, providing a buffer from microclimate extremes (Jordan \& Hoffman Black, 2012). Land gastropods require moisture for respiration and locomotion, and humid microenvironments are known to be a prerequisite for the occurrence of many land mollusk species. However, 
511 excessive wet extremes that lead to flooded soils for long periods are not tolerated by most micro

512 snail species buried in the soil (Addison \& Barber 1997). This can be a restrictive situation to

513 Stephadiscus lyratus occurrence as it is shown by the predicted environmental suitability in a

514 narrow range of annual precipitation not surpassing around $1500 \mathrm{~mm}$ per year. Also, this would

515 explain the occurrence of $S$. lyratus in humid areas of Magellanic subpolar forest, and the

516 projected potential environments in some regions of northern Valdivian Temperate Forest, which

517 featured by $1000 \mathrm{~mm}$ of precipitation per year

518 (https://www.worldwildlife.org/ecoregions/nt0404).

519

520 Stephadiscus lyratus, a vulnerable species to protect

521 Stephadiscus lyratus inhabit mostly woody areas of native forests. The preferred microhabitats of

522 the species are sites on or under the bark of fallen trees or under humid logs in contact with the

523 soil. These microhabitats are less frequent in disturbed forest areas with high human pressure

524 located in Tierra del Fuego outside the National Park, where specimens were difficult to find

525 alive. In addition to microclimate effects, coarse woody debris has a significant influence on

526 gastropod food availability. Dead and decaying wood promotes a diversity of fungi, an important

527 food resource for many snails. Land gastropods are suffering habitat loss and competition from

528 introduced species (more numerous and prolific every year), although are regarded as non-

529 charismatic groups for conservation purposes (Régnier et al., 2009; 2015). In the case of

530 Orthalicoidean land snail in Argentina, only 3\% of their average species distribution ranges are

531 safeguarded within current protected areas, showing that the existing protected areas system is

532 not effective at all for the protection of this invertebrate group (Ovando et al., 2019). In the

533 present study, we found that $14,5 \%$ of the total current distributional area of $72,672 \mathrm{~km}^{2}$ of $S$.

534 lyratus is inside the system of protected areas. However, it is important to emphasize that the

535 threats and pressures of land-use change such as tourism, logging, and frequent fires compromise

536 both, protected areas inside the southern National Parks, and the matrix that surrounds them. In

537 fact, 700-1000 ha are logged each year (from 1980 to 2003) in Argentina, Tierra del Fuego

538 (Gea-Izquierdo et al., 2004. Between 53.1\% and 68.1\% of the Chilean Magellanic forests are

539 influenced by human activity in some way (Inostroza, Zasada \& König, 2016). In this context,

540 habitat loss for land gastropod conservation is very worrying. Moreover, the protected areas in

541 Argentina were created for the protection of plants (Ortega-Baes et al., 2012) and/or vertebrates

Peer] reviewing PDF | (2020:12:56538:2:0:NEW 13 May 2021) 
542 (Tabeni, Bender \& Ojeda, 2004; Arzamendia \& Giraudo, 2004; Corbalán et al., 2011; Tognelli et

543 al., 2011), ignoring the invertebrates, even when their importance has been proven (Chehébar et 544 al., 2013). This situation is a worldwide problem since there are more than a million invertebrate 545 described species but only 3,500 are protected (Baillie, Hilton-Taylor \& Stuart, 2004; Brooks et 546 al., 2004, 2006; Nieto et al., 2017). We sustain that S. lyratus find favorable overwintering 547 microhabitat in soil or under stones in contact with soil, which is well buffered from temperature 548 and moisture fluctuations allowing them to survive during winter freezing. The combination of 549 the ectothermic traits of this species, low dispersal capacity, probable low fecundity producing 550 only a few eggs, and its narrow habitat requirements (forest specialist) turns $S$. lyratus into a 551 potentially vulnerable species. Along with habitat loss through human land use, climate change 552 is a major contributor to biodiversity loss in the 21 st century (Lee et al., 2015). The climate is 553 changing rapidly, and terrestrial ectotherms are expected to be particularly vulnerable to an 554 increase in extreme weather events in temperate regions (Nicolai \& Ansart, 2017). They will be 555 affected seasonally by more frequent hot temperature extremes and fewer cold temperature 556 extremes over most land areas (IPCC, 2014). Meanwhile, the projected precipitation changes 557 show reductions for the dry area in the central-western region and the whole of Patagonia 558 (Barros et al., 2015). In the Magellanean region, there have been reported extreme events that 559 could be increased in frequency and intensity in the context of climate change. Examples of these 560 events were severe droughts (1920-1926, 1928, 1966), heavy rainfall events with floods (1983, 561 1990, 2012, 2015), and devastating snowfall storms. Thus, the quality and availability of habitat

562 for $S$. lyratus could be compromised by the effect of both land uses changes and global warming.

563 In this context, these regional changes in climate and land use put S. lyratus populations at 564 serious risk of extinction that must be taken into consideration for future conservation actions.

565

566 Conclusions

567 1. Here we confirm that the shell ultrastructure of $S$. lyratus has a protoconch and teleoconch 568 with similar ornamentation, not showing a marked limit between them. We provide new 569 anatomical information highlighting the presence of a be-lobed kidney, a close secondary ureter, 570 and the terminal portion of the uterus (spermoviduct) forming a compact glandular mass, the vas

571 deferens inserting into the epiphallus through a dilatation as the most notable anatomical 572 characters of S. lyratus. 
573 2. The potential distribution obtained shows that $S$. lyratus could be found beyond the

574 Magellanic Subpolar Forests into the Valdivian Temperate Forest, which would increase its

575 known distribution area to a new sub-ecoregion, mainly within Chile.

576 3. From seven environmental abiotic variables used, the main constraining ones to explain $S$.

577 lyratus occurrence in the EGD are the temperature (Isothermality, Minimum temperature of

578 coldest month, and Temperature seasonality) and Annual precipitation.

579 4. Stephadiscus lyratus inhabits cold native forest areas where it is found mainly on or under the

580 bark of fallen trees or damp trunks in contact with the ground. This microhabitat allows them

581 overwintering, buffered from temperature and moisture fluctuations, and survive during winter,

582 probably as a strategy to avoid freezing.

583 5. The combination of its narrow habitat requirements (forest specialist), the ectothermic traits of

584 this species, and its low dispersal capacity turn S. lyratus into a potentially vulnerable species, to 585 current land-use change, and future climate change scenarios.

586

587 Acknowledgment

588 We would like to thank the curators and researchers from the different collections and databases

589 consulted, Alejandro Tablado and Sergio Miquel (MACN-In); Gustavo Darrigran (MLP);

590 (NMNH); Museum of Comparative Zoology (MCZ), and the Academy of Natural Sciences in

591 Philadelphia (ANSP). To the National Parks agency of Argentina for providing permits to work

592 in Tierra del Fuego, Los Alerces, and Nahuel Huapi National Parks. A special thanks to the Los

593 Alerces park rangers, Florencia Pantasso, and Dario Bassoso, who kindly support and facilitate

594 all fieldwork. MGC would like to thank the Centro Austral de Investigaciones Científicas

595 (CADIC-CONICET) for allowing us to use their facilities during December 2018 and January

5962019 for this research. A special thanks to Christopher Anderson, who kindly offered space in

597 his laboratory and helped to obtain all permits to work in Tierra del Fuego. To Marina

598 Tagliaferro for her kindness and support in the CADIC microscopy laboratory. To Christopher

599 Anderson and Alejandro Valenzuela for their kind hospitality while in Ushuaia. To A. Lira-

600 Noriega and L. Osorio-Olvera for teaching and supporting us with the methodology and use of

601 the Kuenm package for R. We thanks the Editor, JJ. Morrone, and the reviewers, E. Martínez- 
602 Meyer, T. Escalante, and an anonymous reviewer for providing valuable comments on the 603 manuscript. 
604 References

605 Addison, J.A. and K.N. Barber. 1997. Response of soil invertebrates to clearcutting and partial

606 cutting in a boreal mixedwood forest in Northern Ontario. Natural Resources Canada, 607 Canadian Forest Service, Great Lakes Forestry Centre. Information Report GLC-X-1. 23

608 pp. Available at http://cfs.nrcan.gc.ca/pubwarehouse/pdfs/9135.pdf

609 Ansart A, Vernon P. 2003. Cold hardiness in molluscs. Acta Oecologica 24:95-102 DOI:

$610 \quad 10.1016 / \mathrm{S} 1146-609 \mathrm{X}(03) 00045-6$.

611 Arino O, Ramos Perez JJ, Kalogirou V, Bontemps S, Defourny P, Van Bogaert E. 2012. Global

612 Land Cover Map for 2009 (GlobCover 2009). European Space Agency (ESA) \& Universit

613 Catholique de Louvain (UCL) DOI: 10.1594/PANGAEA.787668.

614 Armesto JJ, Rozzi R and Caspersen J. 2001. Temperate forests of North and South America. In:

615 Chapin F.S., Sala O.E. and Huber-Sannwald E. (eds), Global Biodiversity in a Changing

616 Environment. Scenarios for the 21st Century. Springer, New York, pp. 223-249.

617 Arzamendia V, Giraudo AR. 2004. Usando patrones de biodiversidad para la evaluación y diseño

618 de áreas protegidas: Las serpientes de la provincia de Santa Fe (Argentina) como ejemplo.

619 Revista Chilena de Historia Natural 77: 335-348 DOI: 10.4067/s0716-

$620 \quad 078 \times 2004000200011$.

621 Axelrod DI, Kalin Arroyo MT, Raven PH. 1991. Historical development of temperate vegetation

622 in the Americas. Revista Chilena de Historia Natural 64:413-446

623 Baillie JE, Hilton-Taylor C, Stuart SN. 2004. 2004 IUCN red list of threatened species: A global

624 species assessment. Gland, Switzerland and Cambridge, UK: IUCN

625 Barahona-Segovia R, Riveros-Díaz AL, Zaror S, Catalán R, Araya JF. 2019. Shelter,

626 ecophysiology and conservation status of Plectostylus araucanus (Pulmonata:

627 Bothriembryontidae) in the fragmented Maulino Forest, central Chile. Revista Mexicana de 628 Biodiversidad 90: e902703.

629 Barker GM. 2001. Gastropods on land: phylogeny, diversity and adaptive morphology. In: The 630 biology of terrestrial molluscs. CABI, 1-146 DOI: 10.1079/9780851993188.0001.

631 Barros VR, Boninsegna JA, Camilloni IA, Chidiak M, Magrín GO, Rusticucci M. 2015. Climate

632 change in Argentina: Trends, projections, impacts, and adaptation. Wiley Interdisciplinary

633 Reviews: Climate Change 6:151-169 DOI: 10.1002/wcc.316.

634 Barve N, Barve V, Jiménez-Valverde A, Lira-Noriega A, Maher SP, Peterson AT, Soberón J, 
635

636

637

638

639

640

641

642

643

644

645

646

647

648

649

650

651

652

653

654

655

656

657

658

659

660

661

662

663

664

665

Villalobos F. 2011. The crucial role of the accessible area in ecological niche modeling and species distribution modeling. Ecological Modelling 222:1810-1819 DOI:

10.1016/j.ecolmodel.2011.02.011.

Barve N, Barve V. 2019. Package ENMGadgets: pre and post-processing in ENM workflow. Available at https://github.com/narayanibarve/ENMGadgets.

Beltramino AA, Vogler RE, Gutiérrez Gregoric DE, Rumi A. 2015. Impact of climate change on the distribution of a giant land snail from South America: predicting future trends for setting conservation priorities on native malacofauna. Climatic Change 131:621-633 DOI: 10.1007/s10584-015-1405-3.

Brooks TM, Bakarr MI, Boucher T, Da Fonseca GAB, Hilton-Taylor C, Hoekstra JM, Moritz T, Olivieri S, Parrish J, Pressey RL, Rodrigues ASL, Sechrest W, Stattersfield A, Strahm W, Stuart SN. 2004. Coverage provided by the global protected-area system: Is it enough? BioScience 54:1081-1091 DOI: 10.1641/0006-3568(2004)054[1081:CPBTGP]2.0.CO;2.

Brooks TM, Mittermeier RA, Da Fonseca GAB, Gerlach J, Hoffmann M, Lamoreux JF, Mittermeier CG, Pilgrim JD, Rodrigues ASL. 2006. Global biodiversity conservation priorities. Science 313:58-61 DOI: 10.1126/science.1127609.

Chehébar C, Novaro A, Iglesias G, Walker S, Funes M, Tammone M, Didier K. 2013. Identificación de áreas de importancia para la biodiversidad en la estepa y el monte de Patagonia: Valoración en base a distribución de especies y ecosistemas. Buenos Aires, Argentina: APN, WCS, TNC.

Christensen JH, Hewitson B, Busuioc A, Chen A, Gao X, Held I, Jones R, Kolli RK, Kwon W-T, Laprise R, Magaña Rueda V, Mearns L, Menendez CG, Ra“isa“nen J, Rinke A, Sarr A, Whetton P. 2007. Regional climate projections. In: Solomon S, Qin D, Manning M, Chen Z, Marquis M, Averyt KB, Tignor M, Miller L, eds. Climate Change 2007: The Physical Science Basis. Contribution of Working Group I to the Fourth Assessment Report of the Intergovernmental Panel on Climate Change. Cambridge: University Press, 847-940.

Cobos ME, Peterson T, Barve N, Osorio-Olvera L. 2019. Kuenm: An R package for detailed development of ecological niche models using Maxent. PeerJ 2019:1-15 DOI: 10.7717 peerj.6281.

Cobos ME, Osorio-Olvera L, Soberón J, Peterson T, Barve V, Barve N. 2020. ellipsenm: an R package for ecological niche's characterization using ellipsoids. Available at 
666 https://github.com/marlonecobos/ellipsenm.

667 Corbalán V, Tognelli MF, Scolaro JA, Roig-Juñent SA. 2011. Lizards as conservation targets in 668 Argentinean Patagonia. Journal for Nature Conservation 19:60-67 DOI:

$669 \quad$ 10.1016/j.jnc.2010.05.004.

670 Cuezzo MG. 2006. Systematic revision and cladistic analysis of Epiphragmophora Doering from 671 Argentina and southern Bolivia (Gastropoda: Stylommatophora: Xanthonychidae).

672 Malacologia 49:121-188 DOI: 10.4002/1543-8120-49.1.121.

673 Cuezzo MG, Miranda MJ, Vogler RE, Beltramino AA. 2018. From morphology to molecules: a 674 combined source approach to untangle the taxonomy of Clessinia (Gastropoda,

675 Odontostomidae), endemic land snails from the Dry Chaco ecoregion. PeerJ 6:e5986 DOI: $676 \quad 10.7717 /$ peerj.5986.

677 Di Gregorio A. 2005. Land cover classification system. Classification concepts and user manual 678 for software version 2. Rome: Food and Agriculture Organization of the United Nations. 679 Dos Santos D, Domínguez E, Miranda MJ, Gutiérrez Gregoric D, Cuezzo MG. 2020. The 680 relevance of ecoregions and mountainous environments in the diversity and endemism of 681 land gastropods. Progress in Physical Geography: Earth and Environment 1-25 DOI: $682 \quad 10.1177 / 0309133320948839$.

683 Dudley N. 2008. Guidelines for applying protected area management categories Website: 684 www.iucn.org/themes/wcpa.

685 Elith J, Phillips SJ, Hastie T, Dudík M, Chee YE, Yates CJ. 2011. A statistical explanation of 686 MaxEnt for ecologists. Diversity and Distributions 17:43-57 DOI: 10.1111/j.1472$687 \quad$ 4642.2010.00725.x.

688 Escobar LE, Lira-Noriega A, Medina-Vogel G, Townsend Peterson A. 2014. Potential for spread 689 of the white-nose fungus (Pseudogymnoascus destructans) in the Americas: Use of Maxent 690 and NicheA to assure strict model transference. Geospatial Health 9:221-229 DOI: $691 \quad 10.4081 /$ gh.2014.19.

692 Fourcade Y, Engler JO, Rödder D, Secondi J. 2014. Mapping species distributions with 693 MAXENT using a geographically biased sample of presence data: A performance 694 assessment of methods for correcting sampling bias. PLoS ONE 9:1-13 DOI: $695 \quad$ 10.1371/journal.pone.0097122.

696 Frangi JL, Barrera MD, Puigdefábregas J, Yapura PF, Arambarri AM, Richter LL. 2004. 
697 698 699 700 701 702 703 704 705 706 707 708 709

Ecología de los bosques de Tierra del Fuego. In: Goya JF, Frangi JL, Arturi MF eds. Ecología y manejo de los bosques de Argentina: Investigación en bosques nativos de Argentina. La Plata, Buenos Aires: Editorial de la Universidad Nacional de La Plata (EDULP).

Gea-Izquierdo G, Pastur GM, Cellini JM, Lencinas MV. 2004. Forty years of silvicultural management in southern Nothofagus pumilio primary forests. Forest Ecology and Management 201: 335-347 DOI: 10.1016/j.foreco.2004.07.015.

Gould AA. 1845-1848. Dr. Gould described the following species of Helix from the shells of the Exploring Expedition. Proceedings of the Boston Society of Natural History II: 165-170.

Gould AA. 1852. The United States Exploring Expedition 1838-1842 under the command of Charles Wilkes. Boston: Mollusks \& Shells.

Guevara L, Gerstner BE, Kass JM, Anderson RP. 2018. Toward ecologically realistic predictions of species distributions: A cross-time example from tropical montane cloud forests. Global Change Biology 24:1511-1522 DOI: https://doi.org/10.1111/gcb.13992.

Hijmans RJ, Cameron SE, Parra JL, Jones PG, Jarvis A. 2005. Very high resolution interpolated climate surfaces for global land areas. International Journal of Climatology 25:1965-1978 DOI: $10.1002 /$ joc. 1276.

Hylton Scott MI. 1964. Helix costellata d'Orbigny, a la luz de su anatomía. Neotropica 10:1519.

Hylton Scott MI. 1968. Endodontidos Neotropicales III. Neotropica 14:99-102.

Hylton Scott MI 1970. Endodontidos de la Región Austral Americana. Revista del Museo Argentino de Ciencias Naturales “Bernardino Rivadavia” X: 267-296.

Hylton Scott MI. 1972. Lista de Gastropoda terrestres, principalmente Endodontidos de Tierra del Fuego, Isla de los Estados e islotes vecinos. Neotropica 18:67-72.

Hylton Scott MI. 1973. Endodontidos Neotropicales V. Neotropica 19:126-131.

Hylton Scott MI. 1981. Referencias al género Stephanoda Albers, 1860 y la creación del género Stephadiscus gen. nov. (Mollusca, Endodontidae). Neotropica 27:123-126.

Inostroza L, Zasada I, König HJ. 2016. Last of the wild revisited: assessing spatial patterns of human impact on landscapes in Southern Patagonia, Chile. Regional Environmental Change 16:2071-2085 DOI: 10.1007/s10113-016-0935-1.

Peer] reviewing PDF | (2020:12:56538:2:0:NEW 13 May 2021) 
727 IPCC. 2014. Climate Change 2014: Synthesis Report. In: Core Writing Team, Pachauri RK, 728 Meyer LA, eds. Contribution of Working Groups I, II, and III to the Fifth Assessment

729

730

731

732

733

734

735

736

737

738

739

740

741

742

743

744

745

746

747

748

749

750

751

752

753

754

755

756

757

Report of the Intergovernmental Panel on Climate Change. Geneva, Switzerland: IPCC, 151.

IUCN, UNEP-WCMC. 2020. The World Database on Protected Areas (WDPA), Cambridge, UK: UNEP-WCMC. Available at: $\underline{\text { www.protectedplanet.net. }}$

Johnson RL. 1964. The Recent Mollusca of Augustus Addison Gould. Museum of Natural History. Washington DC: Smithsonian Institution.

Jordan SF, Hoffman Black S. 2012. Effects of Forest Land Management on Terrestrial Mollusks: A Literature Review. The Xerces Society for Invertebrate Conservation Portland, Oregon. Interagency Special Status and Sensitive Species Program USDA Forest Service, Region 6 and USDI Oregon/Washington Bureau of Land Management.

Kerney MP, Cameron RAD. 1979. Field guide to the land snails of Britain and northwest Europe. London, Europe: Collins.

Koštál V, Rozsypal J., Pech P., Zahradníčková H., Šimek P. 2013. Physiological and biochemical responses to cold and drought in the rock-dwelling pulmonate snail, Chondrina avenacea. Journal of Comparative Physiology B: Biochemical, Systemic, and Environmental Physiology 183:749-761. DOI: 10.1007/s00360-013-0749-0.

Kuschel G. 1960. Terrestrial zoology in southern Chile. Proceedings of the Royal Society of London, Series B 152: 540-550.

Lee JR, Maggini R, Taylor MFJ, Fuller RA. 2015. Mapping the Drivers of Climate Change Vulnerability for Australia's Threatened Species. PLoS ONE 10:e0124766 DOI: 10.1371/journal.pone.0124766.

Marcer A, Sáez L, Molowny-Horas R, Pons X, Pino J. 2013. Using species distribution modeling to disentangle realized versus potential distributions for rare species conservation. Biological Conservation 166:221-230 DOI: 10.1016/j.biocon.2013.07.001.

McGlone MS, Lusk CH and Armesto JJ. 2016. Biogeography and ecology of south-temperate forests. New Zealand Journal of Botany 54(2): 94-99. doi:10.1080/0028825x.2016.1162819

Medina RG, Ponssa ML, Aráoz E. 2016. Environmental, land cover, and land use constraints on the distributional patterns of anurans: Leptodacylus species (Anura, Leptodactylidae) from Dry Chaco. PeerJ 2016 DOI: 10.7717/peerj.2605.

Peer) reviewing PDF | (2020:12:56538:2:0:NEW 13 May 2021) 
758 Merow C, Smith MJ, Edwards TC, Guisan A, McMahon SM, Normand S, Thuiller W, Wüest 759 RO, Zimmermann NE, Elith J. 2014. Back to the basics of species distribution modeling: 760 what do we gain from complex versus simple models? Ecography in review:1267-1281

761

762

763

764

765

766

767

768

769

770

771

772

773

774

775

776

777

778

779

780

781

782

783

784

785

786

787

788

DOI: $10.1111 /$ ecog.00845.

Miquel SE, Araya JF. 2013. A new Charopidae from Chile and Argentina, Stephacharopa calderaensis n. gen. and n. sp., with remarks on the taxonomy of the genus Stephadiscus Hylton Scott 1981 (Mollusca: Gastropoda Pulmonata). Archiv fur Molluskenkunde 142:227-235 DOI: 10.1127/arch.moll/1869-0963/142/227-235.

Miquel SE, Barker GM. 2009. New Charopidae from Chilean — Argentine Patagonia:

(Mollusca: Gastropoda: Stylommatophora). Archiv für Molluskenkunde: International Journal of Malacology 138:53-61 DOI: 10.1127/arch.moll/0003-9284/138/053-061.

Miquel SE, Cádiz Lorca FJ. 2008. Araucocharopa gallardoi gen. et sp. n. of Charopidae

(Gastropoda: Stylommatophora: Punctoidea) from Southern Chile. Revista del Museo

Argentino de Ciencias Naturales, Nueva Serie 10:329-339 DOI: 10.22179/revmacn.10.287.

Morello J, Matteucci SD, Rodriguez AF, Silva ME. 2012. Ecorregiones y complejos ecosistémicos argentinos. Buenos Aires: Facultad de Arquitectura, Diseño y Urbanismo.

Morrone JJ. 2015. Biogeographical regionalization of the Andean region. Zootaxa 3936:207-236 DOI: 10.11646/zootaxa.3936.2.3.

Morrone JJ. 2018. Evolutionary Biogeography of the Andean Region. Boca Raton: CRC Press DOI: $10.1201 / 9780429486081$.

Nicolai A, Ansart A. 2017. Conservation at a slow pace: Terrestrial gastropods facing fastchanging climate. Conservation Physiology 5 DOI: 10.1093/conphys/cox007.

Niemelä, J., 1997. Invertebrates and boreal forest management. Conservation Biology 11: 601610.

Nieto C, Ovando XMC, Loyola R, Izquierdo A, Romero F, Molineri C, Rodríguez J, Rueda Martín P, Fernández H, Manzo V, Miranda MJ. 2017. The role of macroinvertebrates for conservation of freshwater systems. Ecology and Evolution 7:5502-5513 DOI: 10.1002/ece3.3101.

Olson DM, Dinerstein E. 1998. The global 200: A representation approach to conserving the earth's most biologically valuable ecoregions. Conservation Biology 12:502-515 DOI: 10.1046/j.1523-1739.1998.012003502.x.

Peer) reviewing PDF | (2020:12:56538:2:0:NEW 13 May 2021) 
789 Olson DM, Dinerstein E, Wikramanayake ED, Burgess ND, Powell GVN, Underwood EC, 790 D’Amico JA, Itoua I, Strand HE, Morrison JC, Loucks CJ, Allnutt TF, Ricketts TH, 791 Kura Y, Lamoreux JF, Wettengel WW, Hedao P, Kassem KR. 2001. Terrestrial

792

793

794

795

796

797

798

799

800

801

802

803

804

805

806

807

808

809

810

811

812

813

814

815

816

817

818

819

ecoregions of the world: A new map of life on Earth. BioScience 51:933-938 DOI:

10.1641/0006-3568(2001)051[0933:TEOTWA]2.0.CO;2.

Ortega-Baes P, Bravo S, Sajama J, Sühring S, Arrueta J, Sotola E, Alonso-Pedano M, GodoyBürki AC, Frizza NR, Galíndez G, Gorostiague P, Barrionuevo A, Scopel A. 2012. Intensive field surveys in conservation planning: Priorities for cactus diversity in the Saltenian Calchaquíes Valleys (Argentina). Journal of Arid Environments 82:91-97 DOI: 10.1016/j.jaridenv.2012.02.005.

Osorio-Olvera L, Lira-Noriega A, Soberón J, Peterson AT, Falconi M, Contreras-Díaz RG, Martínez-Meyer E, Barve V, Barve N. 2020. ntbox: An r package with graphical user interface for modeling and evaluating multidimensional ecological niches. Methods in Ecology and Evolution 11:1199-1206 DOI: 10.1111/2041-210X.13452.

Ovando XMC, Miranda MJ, Loyola R, Cuezzo MG. 2019. Identifying priority areas for invertebrate conservation using land snails as models. Journal for Nature Conservation 50:125707 DOI: 10.1016/j.jnc.2019.04.004.

Owens HL, Campbell LP, Dornak LL, Saupe EE, Barve N, Soberón J, Ingenloff K, Lira-Noriega A, Hensz CM, Myers CE, Peterson AT. 2013. Constraints on interpretation of ecological niche models by limited environmental ranges on calibration areas. Ecological Modelling 263:10-18 DOI: 10.1016/j.ecolmodel.2013.04.011.

Pena JC de Castro, Kamino LHY, Rodrigues M, Mariano-Neto E, de Siqueira MF. 2014. Assessing the conservation status of species with limited available data and disjunct distribution. Biological Conservation 170:130-136 DOI: 10.1016/j.biocon.2013.12.015.

Peterson AT, Papeş M, Eaton M. 2007. Transferability and model evaluation in ecological niche modeling: A comparison of GARP and Maxent. Ecography 30:550-560 DOI: 10.1111/j.2007.0906-7590.05102.x.

Peterson AT, Soberón J, Pearson RG, Anderson RP, Martínez-Meyer E, Nakamura M, Araújo MB. 2011. Ecological Niches and Geographic Distributions (MPB-49). Princeton and Oxford: Princeton University Press DOI: 10.1515/9781400840670.

Phillips SJ, Anderson RP, Schapire RE. 2006. Maximum entropy modeling of species

Peer) reviewing PDF | (2020:12:56538:2:0:NEW 13 May 2021) 
820

821

822

823

824

825

826

827

828

829

830

831

832

833

834

835

836

837

838

839

840

841

842

843

844

845

846

847

848

849

850

geographic distributions. Ecological Modelling 190:231-259 DOI:

10.1016/j.ecolmodel.2005.03.026.

Phillips SJ, Dudík M. 2008. Modeling of species distributions with Maxent: new extensions and a comprehensive evaluation. Ecography 31:161-175 DOI: 10.1111/j.09067590.2008.5203.x.

Régnier C, Fontaine B, Bouchet P. 2009. Not knowing, not recording, not listing: numerous unnoticed mollusk extinctions. Conservation Biology 23: 1214-1221.

Régnier C, Achaz G, Lambert A, Cowie RH, Bouchet P, Fontaine B. 2015. Mass extinction in poorly known taxa. Proceeding of Natural Academy of Sciences 112: 7761-7766.

Salvador RB, Brook FJ, Shepherd LD, Kennedy M. 2020. Molecular phylogenetic analysis of Punctoidea (Gastropoda, Stylommatophora). Zoosystematics and Evolution 96:397-410 DOI: $10.3897 /$ zse.96.53660.

Schneider CA, Rasband WS, Eliceiri KW. 2012. NIH Image to ImageJ: 25 years of image analysis. Nature Methods 9:671-675. DOI: 10.1038/nmeth.2089.

Smith C. 2017. Southern South America: Chile and Argentina. In: Terrestrial Ecoregions of Latin America and the Caribbean, World Wildlife Fund. WWF NT0404. Available at https://www.worldwildlife.org/ecoregions/nt0404. (accessed 20 November 2017).

Soberón J, Peterson AT. 2005. Interpretation of Models of Fundamental Ecological Niches and Species ' Distributional Areas. Biodiversity Informatics 2:1-10 DOI: 10.1093/wber/lhm022.

Solem A. 1982. Endodontoid land snails from Pacific Islands (Mollusca : Pulmonata :

Sigmurethra). Chicago: Field Museum of Natural History DOI: 10.5962/bhl.title.2553.

Stanisic J. 1990. Systematics and biogeography of eastern Australian Charopidae (Mollusca, Pulmonata) from subtropical rainforests. Memoirs of the Queensland Museum 30:1-241.

Syfert MM, Joppa L, Smith MJ, Coomes DA, Bachman SP, Brummitt NA. 2014. Using species distribution models to inform IUCN Red List assessments. Biological Conservation 177:174-184 DOI: 10.1016/j.biocon.2014.06.012.

Tabeni S, Bender BJ, Ojeda RA. 2004. Estudio de los puntos calientes para la conservación de mamíferos en la Provincia de Tucumán. Mastozoología Neotropical 11:55-67.

Tognelli MF, Abba AM, Bender JB, Seitz VP. 2011. Assessing conservation priorities of xenarthrans in Argentina. Biodiversity and Conservation 20:141-151 DOI: 10.1007/s10531010-9951-5. 
851 Villagrán C, Hinojosa LF. 1997. Historia de los bosques del sur de Sudamérica, II: Análisis 852 fitogeográfico. Revista Chilena de Historia Natural 70:241-267.

853 Vogler RE, Beltramino AA, Sede MM, Gutierres Gregoric DE, Núñez V, Rumi A. 2013. The 854 Giant African Snail, Achatina fulica (Gastropoda: Achatinidae): Using Bioclimatic Models

855 to Identify South American Areas Susceptible to Invasion. American Malacological 856 Bulletin 31:39-50 DOI: 10.4003/006.031.0115.

857 Weaver KF, Anderson T, Guralnick R. 2006. Combining phylogenetic and ecological niche 858 modeling approaches to determine the distribution and historical biogeography of Black 859 Hills mountain snails (Oreohelicidae). Diversity and Distributions 12: 756-766.

860 Wiens JJ, Graham CH. 2005. Niche Conservatism: Integrating Evolution, Ecology, and 861 Conservation Biology. Annual Review of Ecology, Evolution, and Systematics 36:519-539 862 DOI: 10.1146/annurev.ecolsys.36.102803.095431.

863 Wyman J. 1903. Biographical memoir of Augustus Addison Gould. National Academy of 864 Sciences 91-113. 


\section{Figure 1}

Study area and collection points of Stephadiscus lyratus.

(A) Magellanic Subpolar Forest, Valdivian Temperate Forest and Patagonian steppe sub ecoregions showing historic records of occurrence. (B) Southern portion of Tierra del Fuego with new records of occurrences. (C) (D) Aspect of the Magellanic subpolar forest trees, mainly corresponding to the genus Nothofagus, where the studied species was collected. 

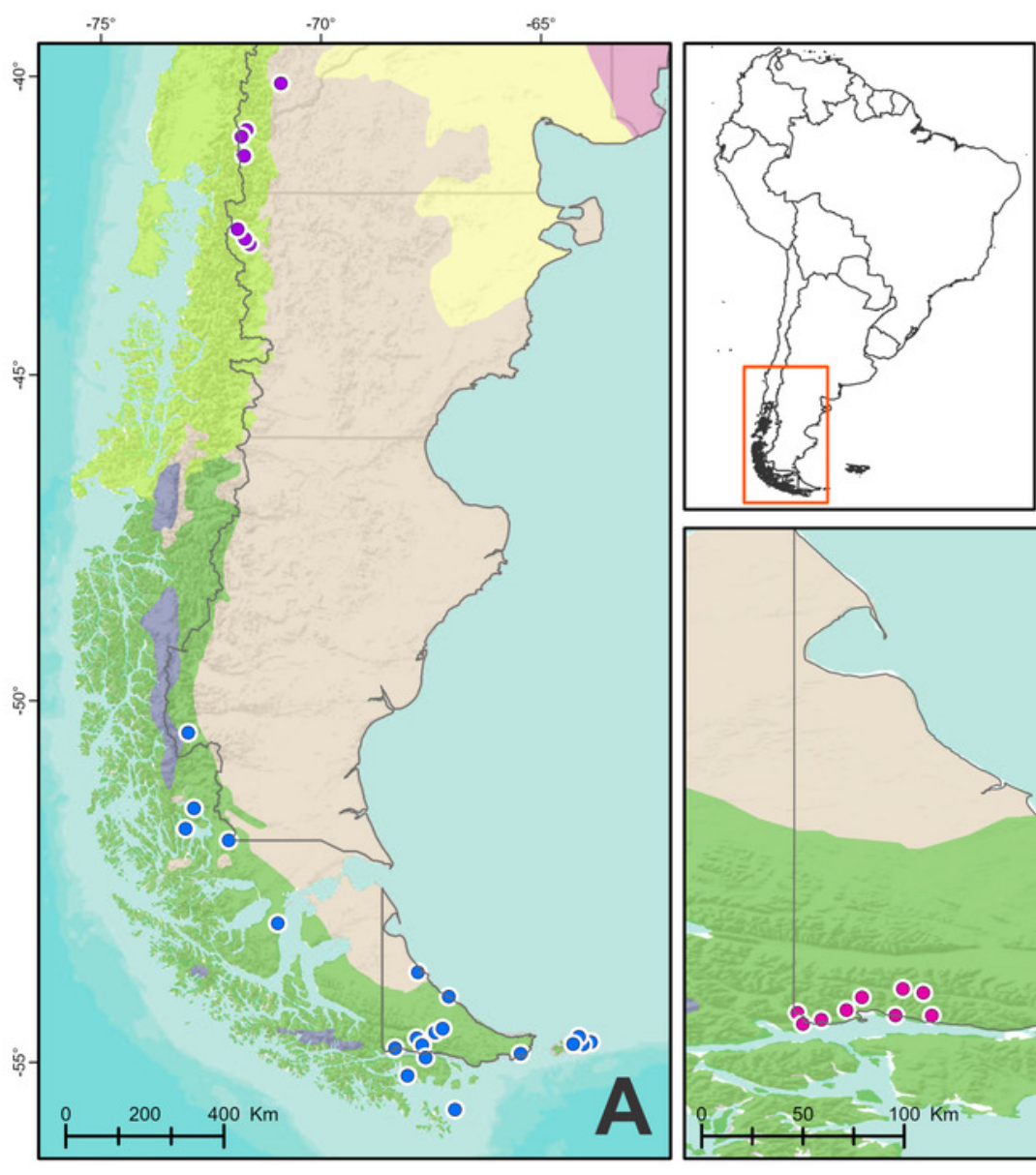

Magellanic subpolar forests

Valdivian temperate forests

Low Monte

Espinal

Rock and Ice

Patagonian steppe

- Historic records

- New records in the Magellanic forest

- New Valdivian forest sites where

S. lyratus did not occur
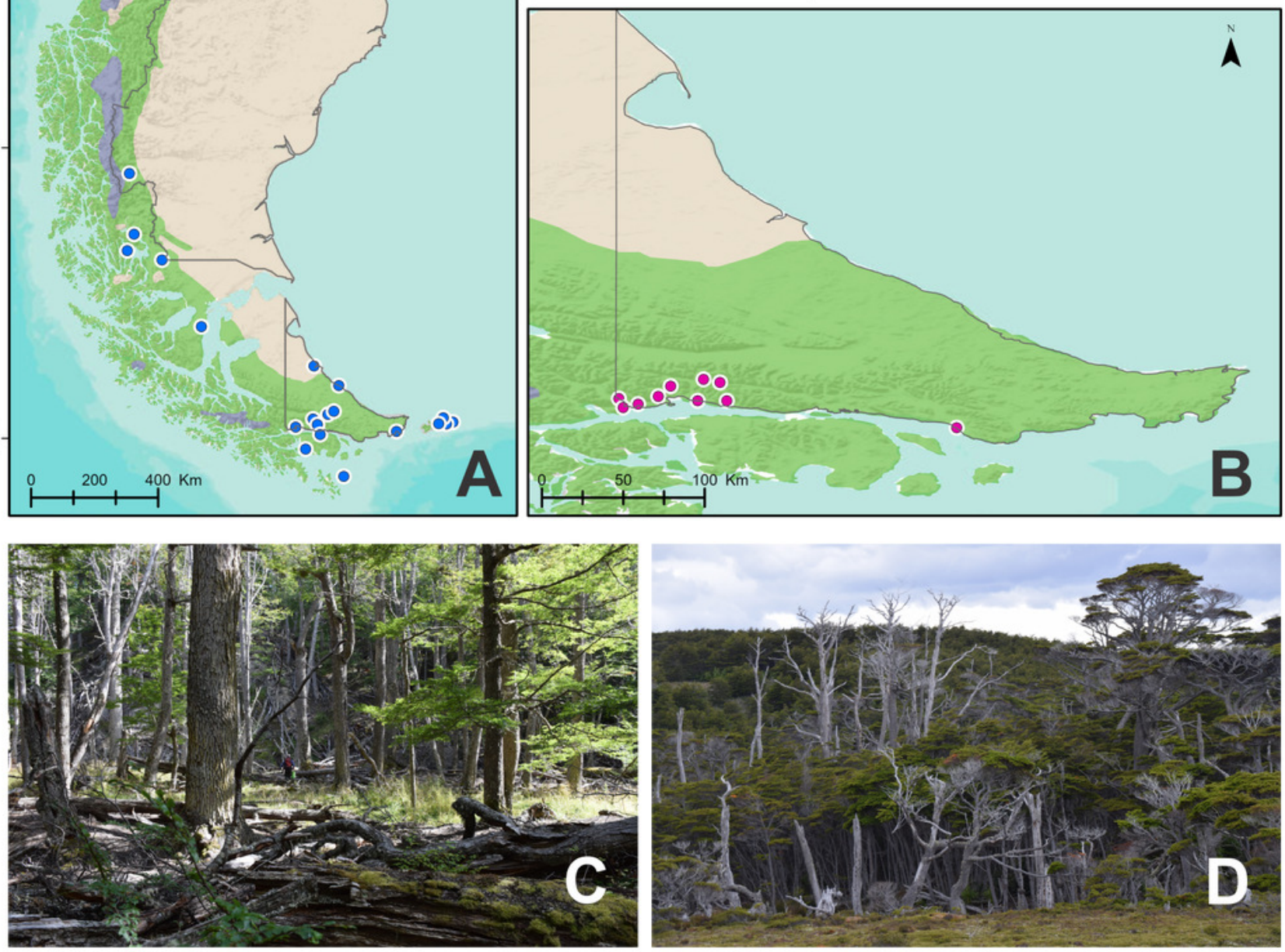


\section{Figure 2}

External morphology of Stephadiscus lyratus shell and live animal.

(A) (B) Live animal from Tierra del Fuego National Park showing natural shell coloration and by transparency, the irregular spots of the lung. Note black animal body with lighter basal foot and mantle collar. (C) Dorsal, (D) ventral and (E) lateral views of shell, scale bar $=1 \mathrm{~mm}$ (IBN 951). Photo credit: MG Cuezzo.

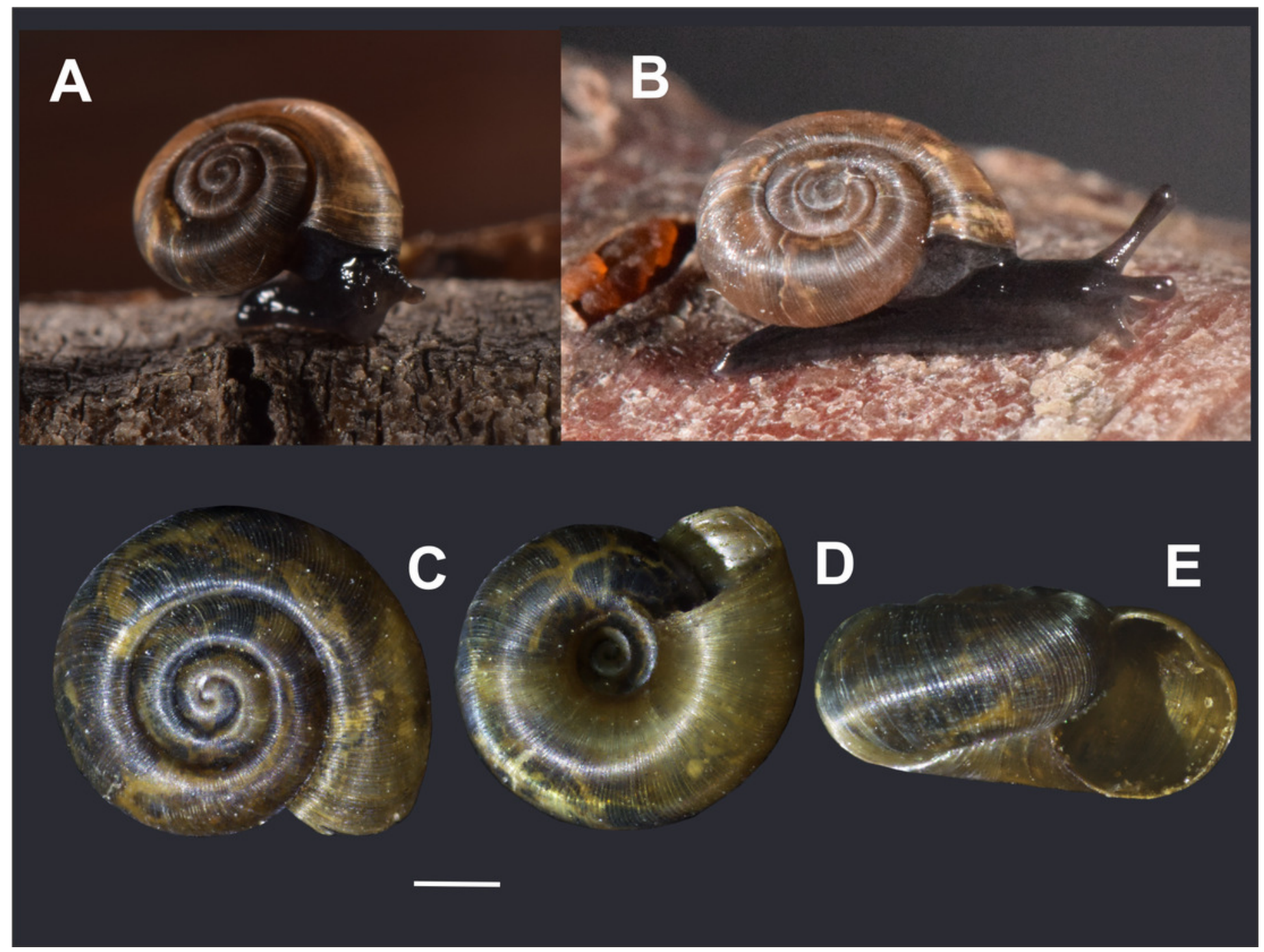




\section{Figure 3}

Shell ultrastructure of Stephadiscus lyratus.

(A) Ultrastructure of protoconch showing the radial disposition of major ribs, scale bar $=100$

$\mu \mathrm{m}$. (B) (C) details of the body whorl sculpture with major ribs separated at regular spaces, and micro radial ribs. Note nodules supporting ribs, scale bar $=10 \mu \mathrm{m}$. (D) Deep suture between body whorls and penultimate whorl, scale bar $=10 \mu \mathrm{m}$. (E) Shell umbilicus with sculpture, scale bar=20 $\mu \mathrm{m}$. Photo credit: MG Cuezzo.
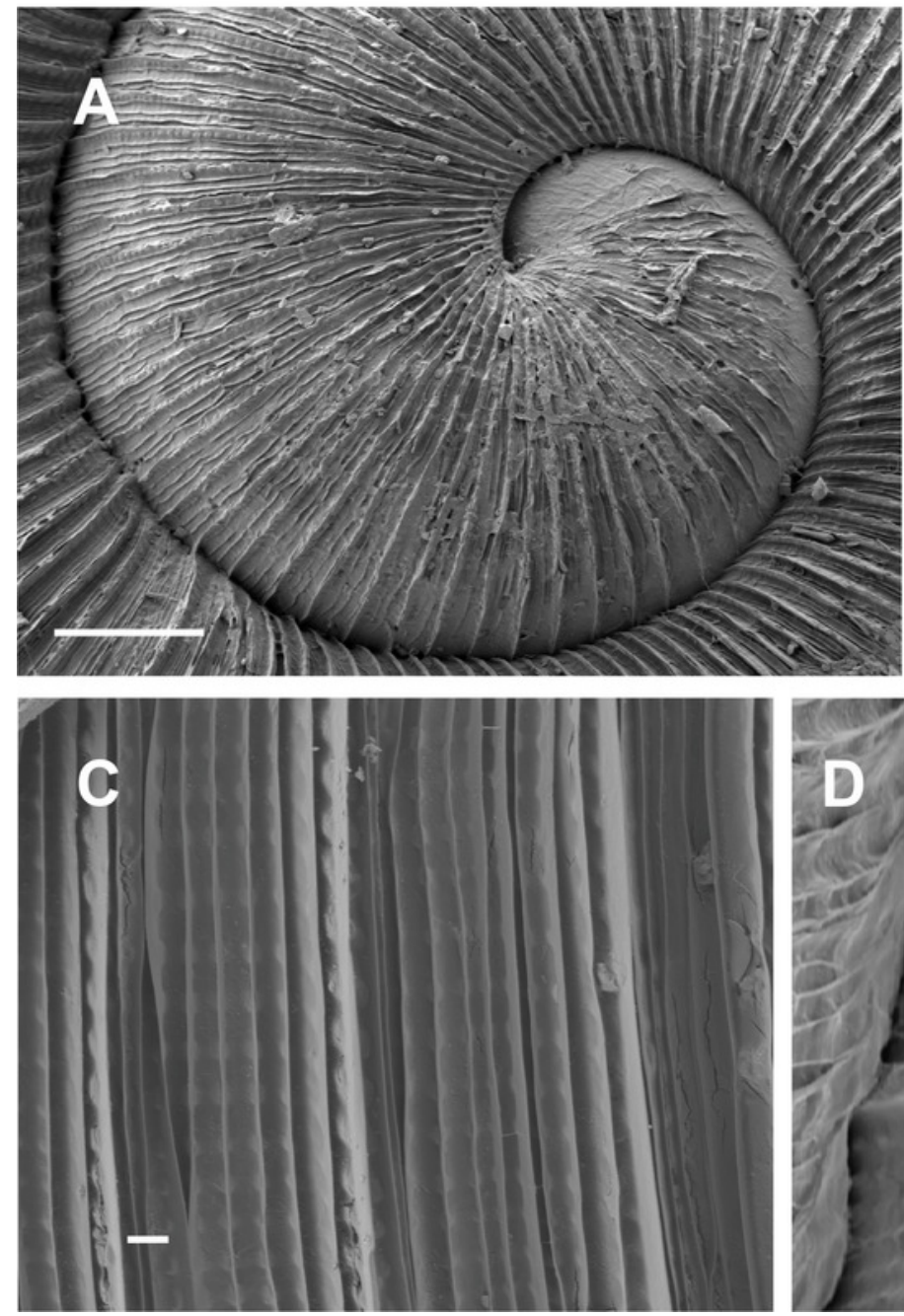
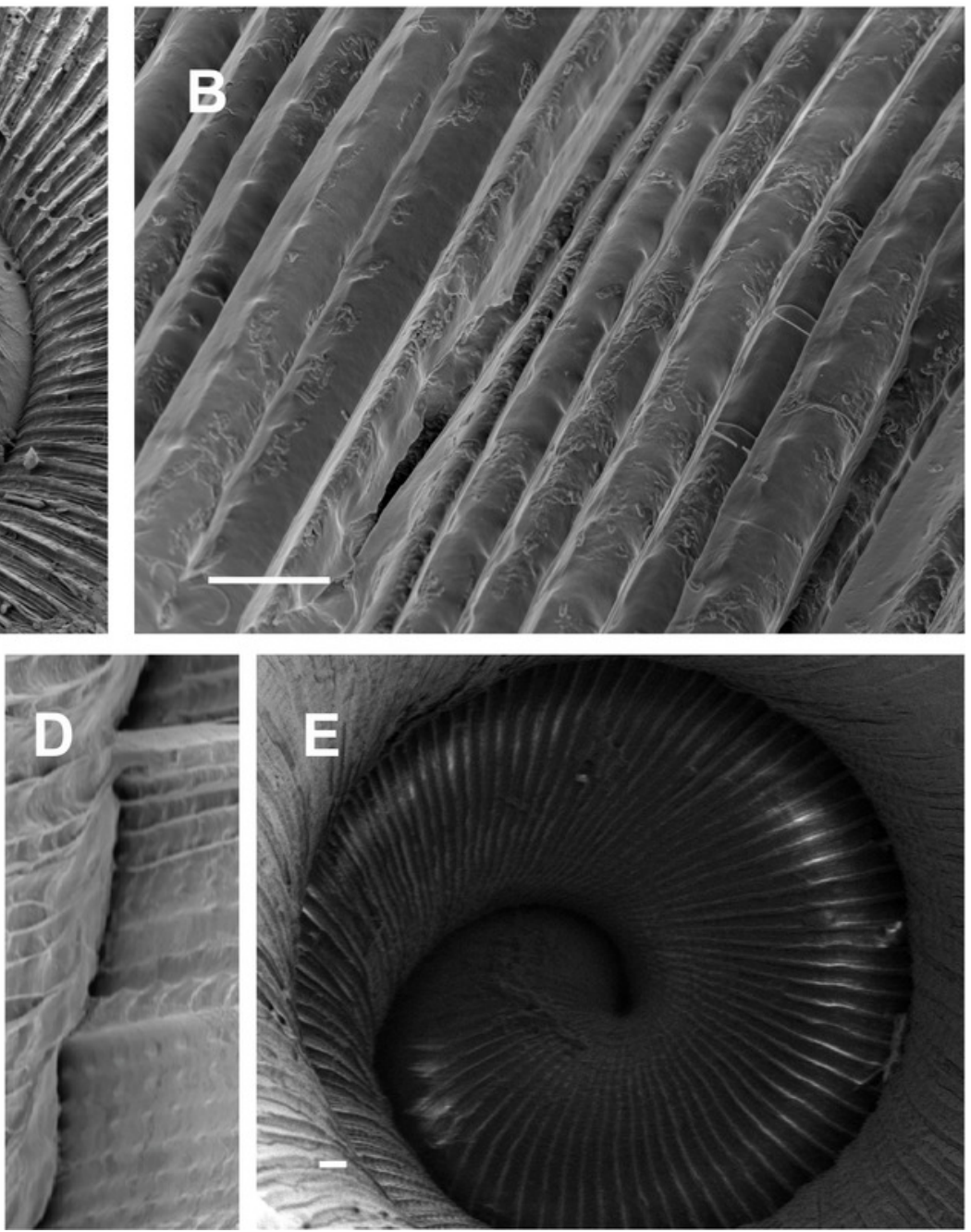


\section{Figure 4}

Morphology of pallial and reproductive systems of Stephadiscus lyratus.

(A) Pallial system with pulmonary and pericardial cavity. Note the beloved kidney overlapping the pericardium. Small whitish concretion are scatter along the pulmonary roof. (B) General shape of reproductive system showing large, rounded albumen gland and spermoviduct divided in two portions, proximal short, cylindrical, continuous to albumen gland, distal expanded in rounded glandular chamber, scale bar= two $\mathrm{mm}$. (C) Detail of the uterus chamber in distal spermoviduct, free oviduct cylindrical, short, scale bar= two mm. (D) Duct of bursa copulatrix with basal widening, sac rounded. (E) Detail of the penial complex showing penis with a sac-like appendix. The epiphallus reflected over penis, is continuous with a short finger-like flagellum. Note that the vas deference is delated before inserting into epiphallus and that the dilatation is as long as the flagellum, giving appearance of fork ending epiphallus, scale bar= two mm. Abbreviations: ag, albumen gland; bc, bursa copulatrix; dbc, bursa copulatrix duct; e, epiphallus; f, flagellum; fo, free oviduct; hd, hermaphroditic duct; kI1, pericardial side kidney lobe; kl2, rectal side kidney lobe; mc, mantle collar; $p$, penis, pr, penial retractor; r, rectum; s, Spermoviduct; su, secondary ureter; $u$, uterus; v, vagina; vd, vas deferens. 


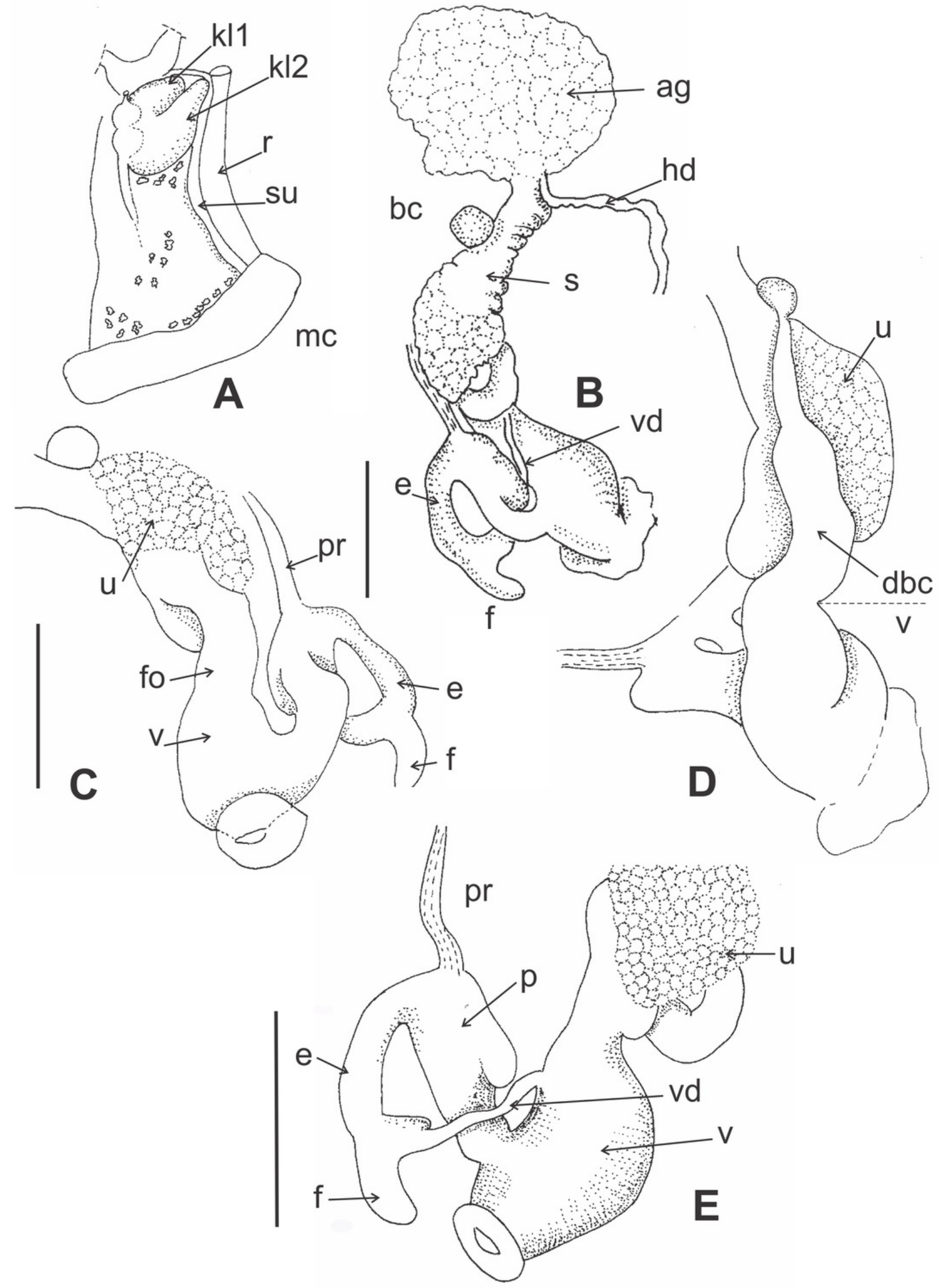




\section{Figure 5}

Response curves for the most important variables in the Maxent model for the environmental suitability of Stephadiscus lyratus.

(A) BIO3:Isothermality, (B) BIO4: Seasonality, (C) BIO6: Minimum temperature of the coldest month, and (D) BIO12: Annual precipitation. The red lines indicate the mean values, while blue areas denote 1 standard deviation limits, resulting from bootstrap replicates in model runs.
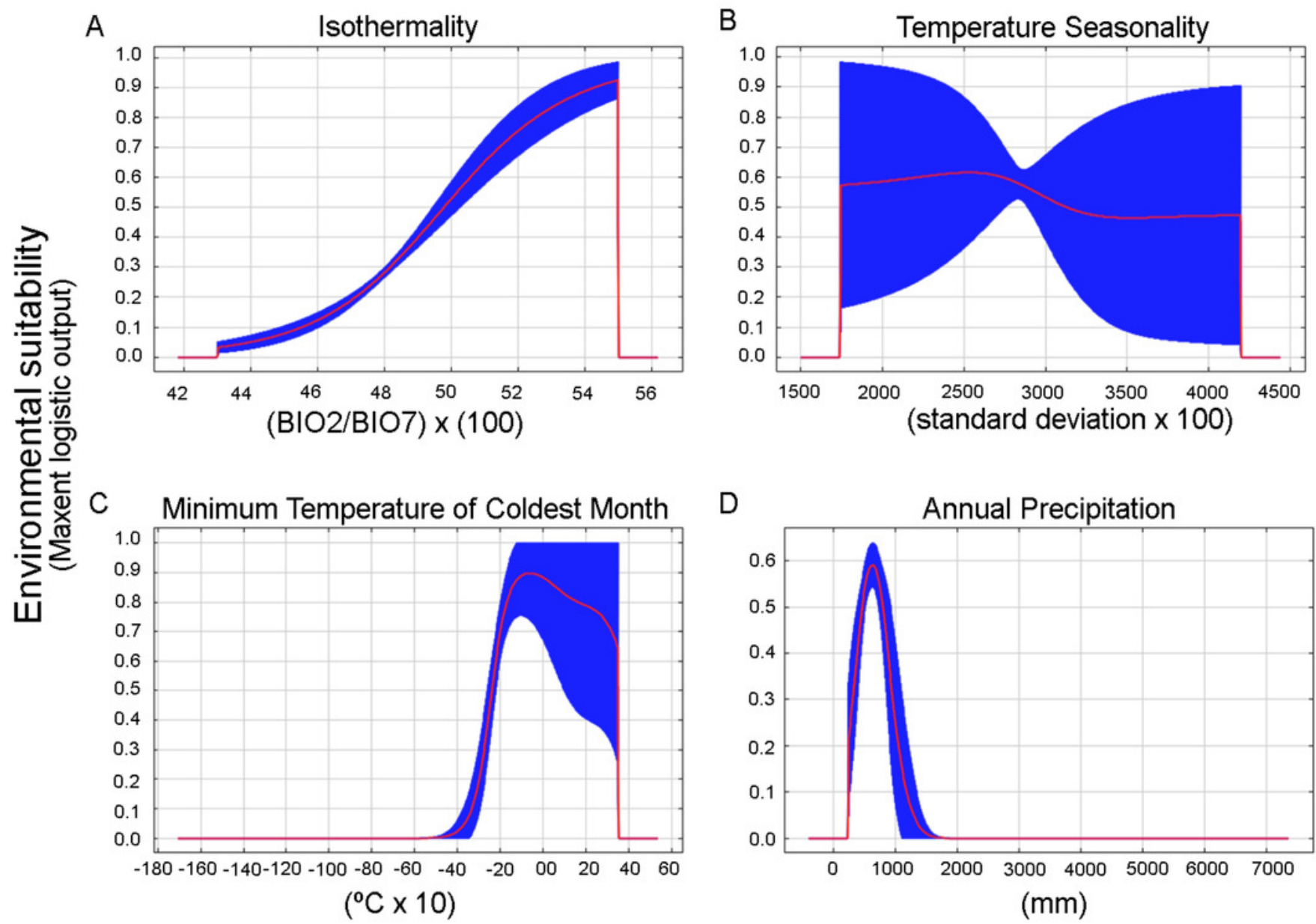


\section{Figure 6}

Estimated and Potential areas of occurrence of Stephadiscus lyratus

(A) Valdivian Temperate Forest and Magellanic Subpolar Forest sub ecoregions, showing "M" area and the estimated geographic distribution (EGD). (B) Final model transferred to region "G", with the potential area of distribution of Stephadiscus lyratus. Note that areas of the model coincident with the Valdivian Temperate Forest mostly occur in the Chilean portion of the sub ecoregion.

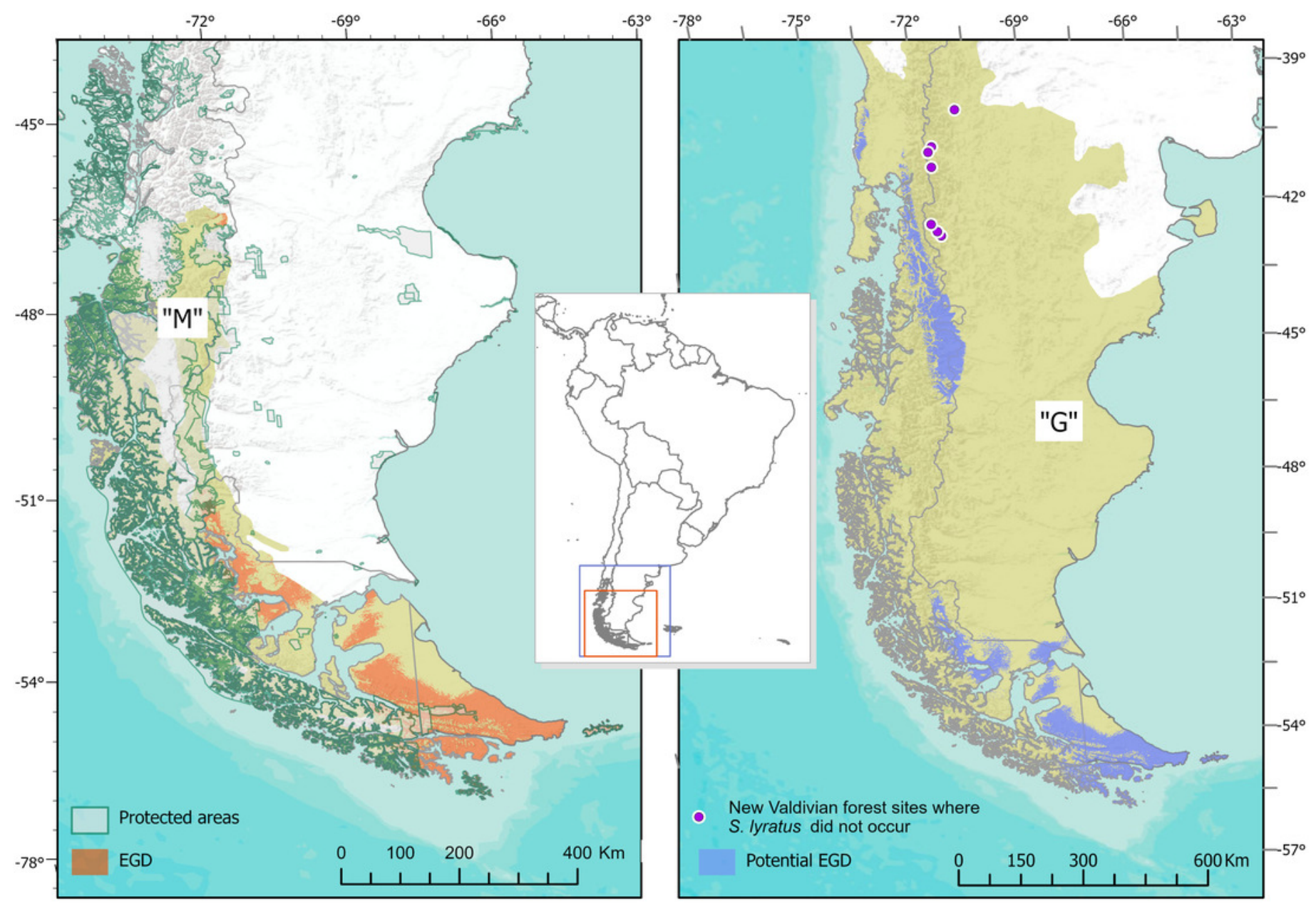




\section{Table $\mathbf{1}$ (on next page)}

Percentages of overlap of the distribution model of Stephadiscus lyratus and occurrence points with land cover categories from Globcover 2009 dataset (UCLouvain \& ESA Team). 


\section{Landcover}

Closed to open $(>15 \%)$ broadleaved evergreen or semi-deciduous forest $(>5 \mathrm{~m})$

Closed to open $(>15 \%)$ (broadleaved or needleleaved, evergreen or deciduous) shrubland $(<5 \mathrm{~m})$

Closed $(>40 \%)$ broadleaved deciduous forest $(>5 \mathrm{~m})$

Closed to open ( $>15 \%$ ) herbaceous vegetation (grassland, savannas or lichens/mosses)

Mosaic cropland (50-70\%) / vegetation (grassland/shrubland/forest) (20-50\%)

Mosaic vegetation (grassland/shrubland/forest) (50-70\%) / cropland (20-50\%)

Rainfed croplands

Open (15-40\%) broadleaved deciduous forest/woodland $(>5 \mathrm{~m})$

Water bodies and Others

\begin{tabular}{cc}
\multicolumn{2}{c}{ Overlapping (\%) } \\
EGD & Ocurrences \\
48.67 & 33.33 \\
21.04 & 30.77 \\
5.77 & 0.00 \\
4.41 & 12.82 \\
2.66 & 0.00 \\
2.02 & 5.13 \\
1.95 & 0.00 \\
1.75 & 2.56 \\
11.72 & 15.38
\end{tabular}




\section{Table 2 (on next page)}

Protected areas overlapped with distribution model of S. lyratus. Names, IUCN categories, country of origin and number of $S$. lyratus EGD pixels within protected areas. 


\section{NAME OF \\ PROTECTED AREA}

Alberto D'Agostini

Bernardo O'Higgins

Cabo de Hornos

Corazón de la Isla

Isla de los Estados y

Archipiélago de Año

Nuevo

Kawésqar

Laguna Negra

Laguna Parrillar

Los Glaciares

Magallanes

Patagonia

Rio Valdez

Seno Almirantazgo

Tierra del Fuego

Torres del Paine

Yendegaia

\section{DESIGN TYPE}

National Park

National Park

National Park

Multiple Use Provincial

Reserve

Wilderness Nature Reserve

National Park, National

Reserve

Multiple Use Provincial

Reserve

Forest Reserve

National Park, National reserve and World Heritage Site

Forest Reserve

National Park

Multiple Use Provincial

Reserve

Marine and Coastal Protected

Area

National Park

National Park

National Park

\section{IUCN \\ CATEGOR \\ Y \\ $\left(\mathrm{N}^{\circ}\right)$}

II

Chile

Chile

II $\quad$ Chile $\quad 694$

3065

56
VI Argentina

1599

Ib Argentina $\quad 703$

II, IV Chile $\quad 868$

VI Argentina 27

IV Chile

9

II, VI, Not

Applicable*

Argentina

41

IV

Chile

16

II

Chile

11

VI

Argentina

57

IV

Chile

102

II Argentina 932

II Chile 836

II $\quad$ Chile $\quad 1687$ 